Prepared in cooperation with the U.S. Department of Energy, National Nuclear Security Administration Nevada Site Office, Office of Environmental Management under Interagency Agreement, DE-A152-07NA28100

\title{
Assessing Hydraulic Connections Across a Complex Sequence of Volcanic Rocks-Analysis of U-20 WW Multiple-Well Aquifer Test, Pahute Mesa, Nevada National Security Site, Nevada
}

Scientific Investigations Report 2011-5173 Version 1.1, June 2016 



\section{Assessing Hydraulic Connections Across a Complex Sequence of Volcanic Rocks-Analysis of U-20 WW Multiple- Well Aquifer Test, Pahute Mesa, Nevada National Security Site, Nevada}

By C. Amanda Garcia, Joseph M. Fenelon, Keith J. Halford, Steven R. Reiner, and Randell J. Laczniak

Prepared in cooperation with the U.S. Department of Energy, National

Nuclear Security Administration Nevada Site Office, Office of Environmental

Management under Interagency Agreement, DE-A152-07NA28100

Scientific Investigations Report 2011-5173

Version 1.1, June 2016 


\title{
U.S. Department of the Interior \\ KEN SALAZAR, Secretary \\ U.S. Geological Survey \\ Marcia K. McNutt, Director
}

\author{
U.S. Geological Survey, Reston, Virginia \\ First release: 2011 \\ Revised: June 2016 (ver 1.1)
}

For more information on the USGS - the Federal source for science about the Earth, its natural and living resources, natural hazards, and the environment, visit http://www.usgs.gov or call 1-888-ASK-USGS.

For an overview of USGS information products, including maps, imagery, and publications, visit http://www.usgs.gov/pubprod

To order this and other USGS information products, visit http://store.usgs.gov

Any use of trade, firm, or product names is for descriptive purposes only and does not imply endorsement by the U.S. Government.

Although this information product, for the most part, is in the public domain, it also may contain copyrighted materials as noted in the text. Permission to reproduce copyrighted items must be secured from the copyright owner.

Suggested citation:

Garcia, C.A., Fenelon, J.M., Halford, K.J., Reiner, S.R., and Laczniak, R.J., 2011, Assessing hydraulic connections across a complex sequence of volcanic rocks-Analysis of U-20 WW multiple-well aquifer test, Pahute Mesa, Nevada National Security Site, Nevada (ver. 1.1, June 2016): U.S. Geological Survey Scientific Investigations Report 2011-5173, 24 p., http://dx.doi.org/10.3133/sir20115173.

ISSN 2328-0328 (online) 


\section{Contents}

Abstract Introduction
Purpose and Scope
Site Description
Hydrogeology
Well Construction
Drawdo Collection
Synthetic Water Levels
Drawdown Analysis
Simulated Drawdown
Hydraulic-Property Estimates
Alternative Fult Interpretation

\section{Figures}

1. Map showing location of aquifer-test wells, underground nuclear tests, geologic structures, and numerical model domain near production well U-20 WW, Nevada

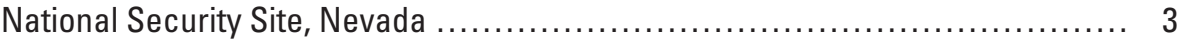

2. Diagram showing simplified well construction and hydrostratigraphic units at production well U-20 WW and observation wells ER-20-6 \#3, UE-20bh 1, and U-20bg, Pahute Mesa, Nevada National Security Site, Nevada $\quad . . \ldots \ldots \ldots \ldots \ldots \ldots . . \ldots$

3. Section showing construction and lithology of production well U-20 WW and observation wells ER-20-6 \#3, UE-20bh 1, and U-20bg, Pahute Mesa, Nevada National Security Site, Nevada .

4. Graphs showing water-level and withdrawal data collected from U-20 WW aquifer test, Pahute Mesa, Nevada National Security Site, Nevada, October 1, 2008-0ctober 1, 2009 ...

5. Graphs showing pumpage from U-20 WW binned three different ways and the effect of binning on the pumping signal at three radial distances $(R)$ from the pumping well, Pahute Mesa, Nevada National Security Site, Nevada ....

6. Graphs showing measured, synthetic, and residual water levels, a Theis transform of the pumping response, and estimated drawdown in observation wells UE-20bh 1, U-20bg, and ER-20-6 \#3, Pahute Mesa, Nevada National Security Site, Nevada

7. Diagram showing model layering and lithologic unit intervals in numerical flow model used to simulate pumping response in production well U-20 WW, Pahute Mesa, Nevada National Security Site, Nevada 


\section{Figures-Continued}

8. Graphs showing comparison of simulated and estimated drawdown data for observation wells used in the numerical flow model, Pahute Mesa, Nevada

National Security Site, Nevada

9. Diagram showing drawdown cone at the end of the third pumping period (day 285) in numerical flow model, Pahute Mesa, Nevada National Security Site, Nevada

10. Graphs showing comparison of West Greeley fault hydraulic conductivity with simulated lava hydraulic conductivity and numerical model unweighted root-mean-square error in well UE-20bh 1, Pahute Mesa, Nevada National Security Site, Nevada

11. Graph showing comparison of simulated and estimated drawdown in well UE-20bh 1 as West Greeley fault hydraulic conductivity (K) varied between 0.01 and 1,000 ft/d, Pahute Mesa, Nevada National Security Site, Nevada

\section{Tables}

1. Characteristics of wells used in U-20 WW aquifer test, Pahute Mesa, Nevada National Security Site, Nevada

2. Estimated drawdown in observation wells during the U-20 WW aquifer test, Pahute Mesa, Nevada National Security Site, Nevada

3. Comparison between simulated and estimated drawdown in observation wells during the U-20 WW aquifer test, Pahute Mesa, Nevada National Security Site, Nevada

4. Hydraulic properties of lithologic units simulated in the numerical flow model for well U-20 WW, Pahute Mesa, Nevada National Security Site, Nevada 


\section{Conversion Factors and Datums}

Conversion Factors

\begin{tabular}{|c|c|c|}
\hline Multiply & By & To obtain \\
\hline \multicolumn{3}{|c|}{ Length } \\
\hline foot (ft) & 0.3048 & meter (m) \\
\hline mile (mi) & 1.609 & kilometer (km) \\
\hline \multicolumn{3}{|c|}{ Area } \\
\hline square foot $\left(\mathrm{ft}^{2}\right)$ & 0.09290 & square meter $\left(\mathrm{m}^{2}\right)$ \\
\hline \multicolumn{3}{|c|}{ Volume } \\
\hline gallon (gal) & 3.785 & liter (L) \\
\hline \multicolumn{3}{|c|}{ Flow rate } \\
\hline gallon per minute (gal/min) & 0.06309 & liter per second (L/s) \\
\hline \multicolumn{3}{|c|}{ Hydraulic conductivity } \\
\hline foot per day (ft/d) & 0.3048 & meter per day $(\mathrm{m} / \mathrm{d})$ \\
\hline \multicolumn{3}{|c|}{ Transmissivity* } \\
\hline foot squared per day ( $\left.\mathrm{ft}^{2} / \mathrm{d}\right)$ & 0.09290 & meter squared per day $\left(\mathrm{m}^{2} / \mathrm{d}\right)$ \\
\hline
\end{tabular}

Temperature in degrees Celsius $\left({ }^{\circ} \mathrm{C}\right)$ may be converted to degrees Fahrenheit $\left({ }^{\circ} \mathrm{F}\right)$ as follows:

$$
\mathrm{F}=\left(1.8 \times{ }^{\circ} \mathrm{C}\right)+32
$$

Datums

Vertical coordinate information is referenced to the National Geodetic Vertical Datum of 1929 (NGVD 29).

Horizontal coordinate information is referenced to the North American Datum of 1927 (NAD 27).

Altitude, as used in this report, refers to distance above the vertical datum.

*Transmissivity: The standard unit for transmissivity is cubic foot per day per square foot times foot of aquifer thickness [(ft $\left.\left.\mathrm{ft}^{3} / \mathrm{d}\right) / \mathrm{ft}^{2}\right] \mathrm{ft}$. In this report, the mathematically reduced form, foot squared per day $\left(\mathrm{ft}^{2} / \mathrm{d}\right)$, is used for convenience. 
This page intentionally left blank. 


\title{
Assessing Hydraulic Connections Across a Complex Sequence of Volcanic Rocks-Analysis of U-20 WW Multiple-Well Aquifer Test, Pahute Mesa, Nevada National Security Site, Nevada
}

\author{
By C. Amanda Garcia, Joseph M. Fenelon, Keith J. Halford, Steven R. Reiner, and Randell J. Laczniak
}

\begin{abstract}
Groundwater beneath Pahute Mesa flows through a complexly layered sequence of volcanic rock aquifers and confining units that have been faulted into distinct structural blocks. Hydraulic property estimates of rocks and structures in this flow system are necessary to assess radionuclide migration near underground nuclear testing areas. The U.S. Geological Survey (USGS) used a 12 month (October 1, 2008-October 1, 2009) intermittent pumping schedule of well U-20 WW and continuously monitored water levels in observation wells ER-20-6 \#3, UE-20bh 1, and U-20bg as a multi-well aquifer test to evaluate hydraulic connections across structural blocks, bulk hydraulic properties of volcanic rocks, and the hydraulic significance of a major fault. Measured water levels were approximated using synthetic water levels generated from an analytical model. Synthetic water levels are a summation of environmental water-level fluctuations and a Theis (1935) transform of the pumping signal from flow rate to water-level change. Drawdown was estimated by summing residual differences between measured and synthetic water levels and the Theis-transformed pumping signal from April to September 2009. Drawdown estimates were used in a three-dimensional numerical model to estimate hydraulic properties of distinct aquifers, confining units, and a major fault.

A maximum water-level drawdown of nearly 0.4 foot in well UE-20bh 1, which is more than 1 mile from the pumping well, was detected across a major fault. Drawdown estimates in the observation well nearest to (ER-20-6 \#3, less than
\end{abstract}

1 mile) and within the same structural block as the pumping well were less than detection ( $<0.1 \mathrm{foot})$. Minimal drawdown within the same structural block indicates that lava units are likely separated by bedded tuff confining units. Hydraulic property estimates indicate that wells U-20 WW, UE-20bh 1 , and ER-20-6 \#3 produce water from moderately permeable fractured lava, as hydraulic conductivity and specific storage estimates average 4.8 feet per day and $2.1 \times 10^{-6}$ per foot, respectively, and transmissivity estimates range from 1,200 to 3,600 feet squared per day. Sensitivity analyses indicate that the major fault is hydraulically similar to the permeable host rock and connects flow between structural blocks.

\section{Introduction}

Understanding groundwater flow is essential for predicting radionuclide transport. Underground nuclear tests on Pahute Mesa periodically occurred near and within volcanic aquifers, releasing contaminants into the groundwater-flow system (Laczniak and others, 1996; Pawloski and others, 2001; Wolfsberg and others, 2002). These volcanic aquifers occur within distinct structural blocks, which are delineated by north-south and east-west trending normal faults that dissect and offset the rocks (Warren and others, 2000). Although the hydraulic connection between structural blocks can greatly affect the direction and distance of contaminant transport, the degree of hydraulic connection is poorly understood because of limited subsurface geologic and hydraulic data. 
Aquifer testing provides the most integrated assessment of hydraulic connectivity within complex geologic systems (Yobbi and Halford, 2008). Drawdown in observation wells that penetrate a structural block different from that intersected by the pumping well provides direct evidence of a hydraulic connection. However, detecting these pumping-induced changes in water-level records typical of Pahute Mesa can be problematic because environmental fluctuations frequently exceed the pumping signal (Halford, 2006a). Environmental fluctuations caused by barometric and tidal forces acting on the aquifer system can trigger a foot or more of water-level change over periods of only a few days (Fenelon, 2000), whereas the expected drawdown in a distant observation well from a relatively large pumping rate of long duration ( $>100 \mathrm{gal} / \mathrm{min}$ and $>24$ hours, respectively) is on the order of $1 \mathrm{ft}$ or less. Additionally, local changes in recharge can cause long-term increasing and decreasing trends that are superimposed on the short-term changes (Fenelon, 2000; Elliot and Fenelon, 2010). These inherent environmental fluctuations must be removed from the water-level record before pumping-induced drawdown and subsequent recovery can be used to estimate hydraulic properties and evaluate the degree of hydraulic connection between structural blocks.

Aquifer-test data from complexly layered aquifers and confining units frequently are interpreted with numerical models to evaluate hydraulic properties of the local geologic system. Numerical simulations combine aquifer-test data with knowledge of hydrogeologic framework to provide a more accurate characterization of complex groundwater systems than analytical models alone (Yobbi and Halford, 2008; Walton, 2008). Hydraulic properties of geologic structures and the effects of these structures on drawdown behavior can be interpreted from aquifer test results because of the flexibility of numerical models (Renard, 2005).

A previous study documented several wells with hydraulically significant downward trending water levels over an 8-10 year period that correlated to long-term pumping of Nevada National Security Site (NNSS) production well U-20 WW (Fenelon, 2000). Although some wells penetrated the same structural block as the pumping well, the strongest correlation was detected in well UE-20bh 1, which is separated from production well U-20 WW by a major fault. The hydraulic significance of fault structures in Pahute Mesa has greatly affected transport assessments (Stoller-Navarro Joint Venture, 2009); yet hydraulic properties are largely based on inference rather than on hydraulic data.
This study is a target of opportunity that uses a 12-month intermittent pumping schedule of production well U-20 WW, as well as continuously monitored water levels in three nearby observation wells, as a multi-well aquifer test to evaluate hydraulic connections across structural blocks, bulk hydraulic properties of intervening volcanic rocks, and the hydraulic significance of a major fault. A simple spreadsheet-based analytical model is used to create synthetic water levels and to estimate drawdown in observation wells both within the same structural block as the pumping well and across a major fault. Drawdown estimates are combined in a numerical MODFLOW model to evaluate the hydraulic significance of underlying complexly layered volcanic rock aquifers, confining units, and a fault structure.

\section{Purpose and Scope}

The purpose of this report is to document a hydraulic connection across a major fault that was observed using a multi-well aquifer test analysis. Water levels in the observation wells (ER-20-6 \#3, UE-20bh 1, and U-20bg) were analytically modeled to compute drawdown from pumping of production well U-20 WW. These drawdown estimates were used to evaluate hydraulic connections within and across structural blocks. Bulk hydraulic properties, such as transmissivity of lava and bedded tuff, specific yield, and specific storage were estimated by combining aquifer test and hydrogeologic framework data in a numerical MODFLOW model. The hydraulic significance of a major fault structure in relation to the host rocks also was investigated using numerical simulations.

\section{Site Description}

The pumped production well (U-20 WW) is located on Pahute Mesa at the NNSS (fig. 1). The locations of the observation wells (ER-20-6 \#3, UE-20bh 1, and $\mathrm{U}-20 \mathrm{bg}$ ), with regard to $\mathrm{U}-20 \mathrm{WW}$, are about 3,570 ft north-northeast, 6,270 ft east-southeast, and 8,020 ft southeast, respectively (ig. 1). 


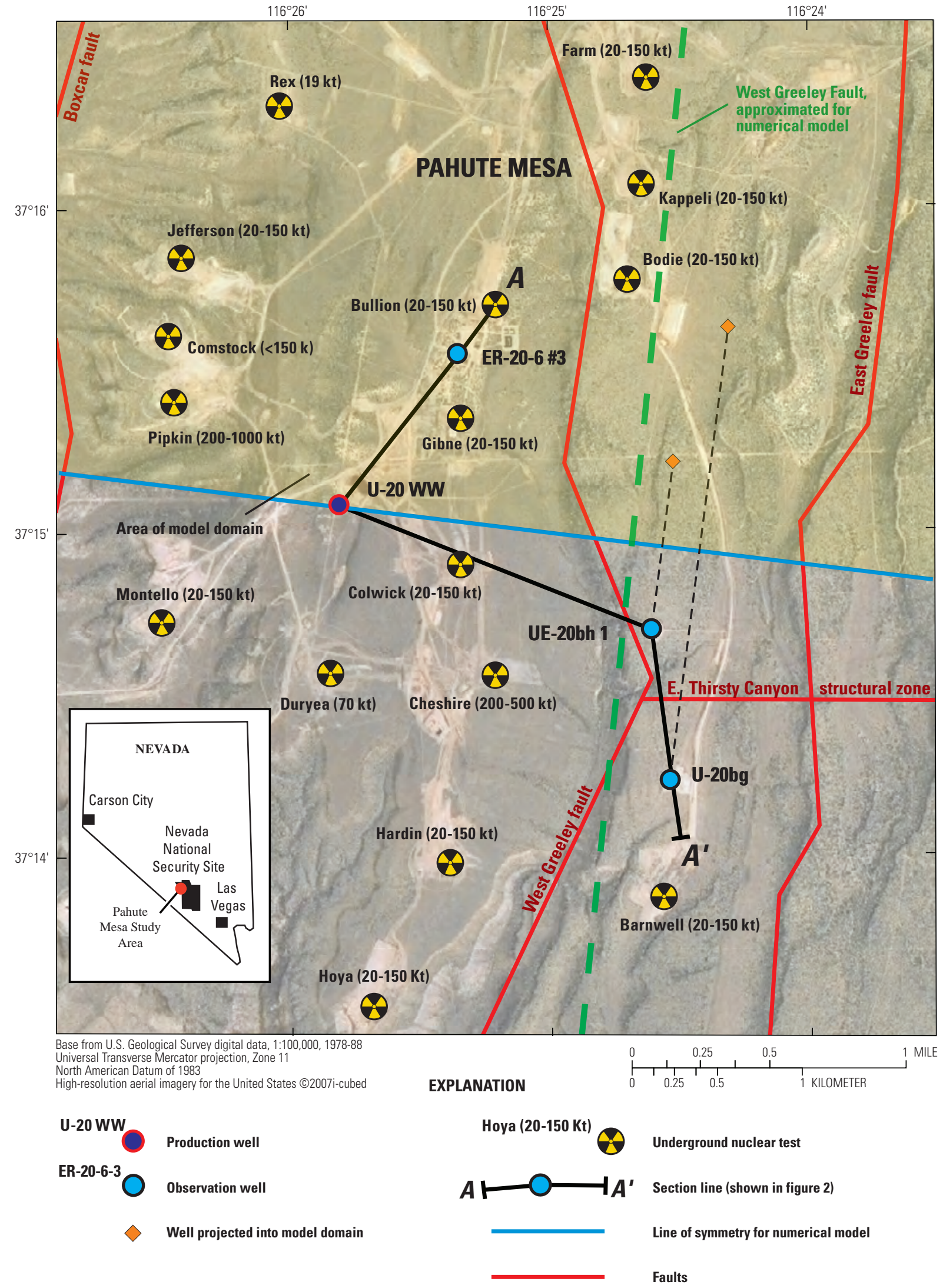

Figure 1. Location of aquifer-test wells, underground nuclear tests, geologic structures, and numerical model domain near production well U-20 WW, Nevada National Security Site, Nevada. (Faults are from Bechtel, 2002; Underground tests are from U.S. Department of Energy, 2000). 


\section{Hydrogeology}

The study area is in an area of underground nuclear testing in eastern and central Pahute Mesa in the northwestern part of the NNSS (fig. 1). Pahute Mesa is an extensive elevated plateau ranging in altitude from about 5,000 to 8,000 ft. Groundwater beneath Pahute Mesa generally flows southwestward, but specific flow paths are uncertain. Much of the groundwater likely discharges to springs southwest of Pahute Mesa (Laczniak and others, 1996; Fenelon and others, 2010).

Production well U-20 WW and observation wells ER-20-6 \#3, UE-20bh 1, and U-20bg were completed in Tertiary volcanic rocks deposited within the Silent Canyon caldera complex in Pahute Mesa (fig. 2). This caldera complex consists of at least two calderas filled with voluminous eruptions of tuff and rhyolitic lava (Sawyer and Sargent, 1989; Prothro and Drellack, 1997; Bechtel, 2002). These wells penetrate about 2,000 ft of unsaturated rock consisting of the following hydrostratigraphic units (Bechtel Nevada, 2002) based on lithologic composition and water-bearing properties: Thirsty Canyon volcanic aquifer, Timber Mountain aquifer, Paintbrush vitric-tuff aquifer, Upper Paintbrush confining unit, and the upper part of the Calico Hills zeolitic composite unit (CHZCM). The local water table occurs in the CHZCM, which is the source of water to all four wells. Typical lithologies within the CHZCM are rhyolite lava flows, and bedded and nonwelded tuffs that commonly are zeolitized (Blankennagel and Weir, 1973; Prothro and Drellack, 1997; Bechtel Nevada, 2002). In this report, the bedded and nonwelded tuffs of the CHZCM will be referred to simply as bedded tuffs.

The CHZCM is a composite hydrogeologic unit composed of a complex distribution of aquifers and confining units that are difficult to map separately with available data (Bechtel Nevada, 2002). Lavas within the CHZCM are permeable and are considered aquifers, whereas tuffs are less permeable and are considered confining units. Bedded tuffs can have very low permeabilities, especially if zeolitized. The lava-flow aquifers have moderate permeabilities, with primary flow through interconnected fractures; however, the degree of hydraulic connection between aquifers is uncertain because the distribution and hydraulic properties of tuff confining units are poorly understood (Blankennagel and Weir, 1973; Laczniak and others, 1996). Total thickness of the CHZCM is estimated to be about 4,200 ft at well U-20 WW; 3,800 ft at well ER-20-6 \#3; 2,300 ft at well UE-20bh 1; and 2,000 ft at well U-20bg (fig. 2).

Normal faults and caldera margin faults occur near well U-20 WW. The West Greeley fault (WGF; McKee and others, 2001) separates wells U-20 WW and ER-20-6 \#3 from wells UE-20bh 1 and U-20bg (figs. 1 and 2). Wells U-20 WW and ER-20-6 \#3 are located on the west (downthrown) side of the WGF whereas wells UE-20bh 1 and U-20bg are located on the east (upthrown) side of the fault. The East Thirsty Canyon structural zone offsets hydrostratigraphic units between wells UE-20bh 1 and U-20bg (figs. 1 and 2). This structural zone is defined by transverse faults and calderamargin faults (Bechtel Nevada, 2002). Faults can influence groundwater flow and might act as conduits or barriers in and of themselves (Laczniak and others, 1996; Faunt, 1997; Caine and Forster, 1999). Faults that transect less permeable rocks might intercept flow, whereas faults that juxtapose less permeable rocks with more permeable rocks might impede flow. Depending on their hydraulic significance, faults that transect permeable rocks can either hydraulically connect or isolate structural blocks.

\section{Well Construction}

Production well U-20 WW was drilled and pumped primarily to support road and pad construction for monitoring wells in the Pahute Mesa area that were drilled since 1985. Well U-20bg was drilled as an emplacement hole for potential testing of a nuclear device, whereas wells ER-20-6 \#3 and UE-20bh 1 were drilled for hydrogeologic investigations. Wells ER-20-6 \#3, UE-20bh 1, and U-20bg were completed in 1996, 1991, and 1990, respectively. Figure 3 provides detailed well-construction information obtained from Fenix \& Scisson, Inc. (written commun., 1982), Raytheon Services Nevada (written commun., 1991), Boyd and others (1992), and U.S. Department of Energy (1998). Well characteristics are described in table 1. Lithologic descriptions for each well are reported in Wood (2009). 

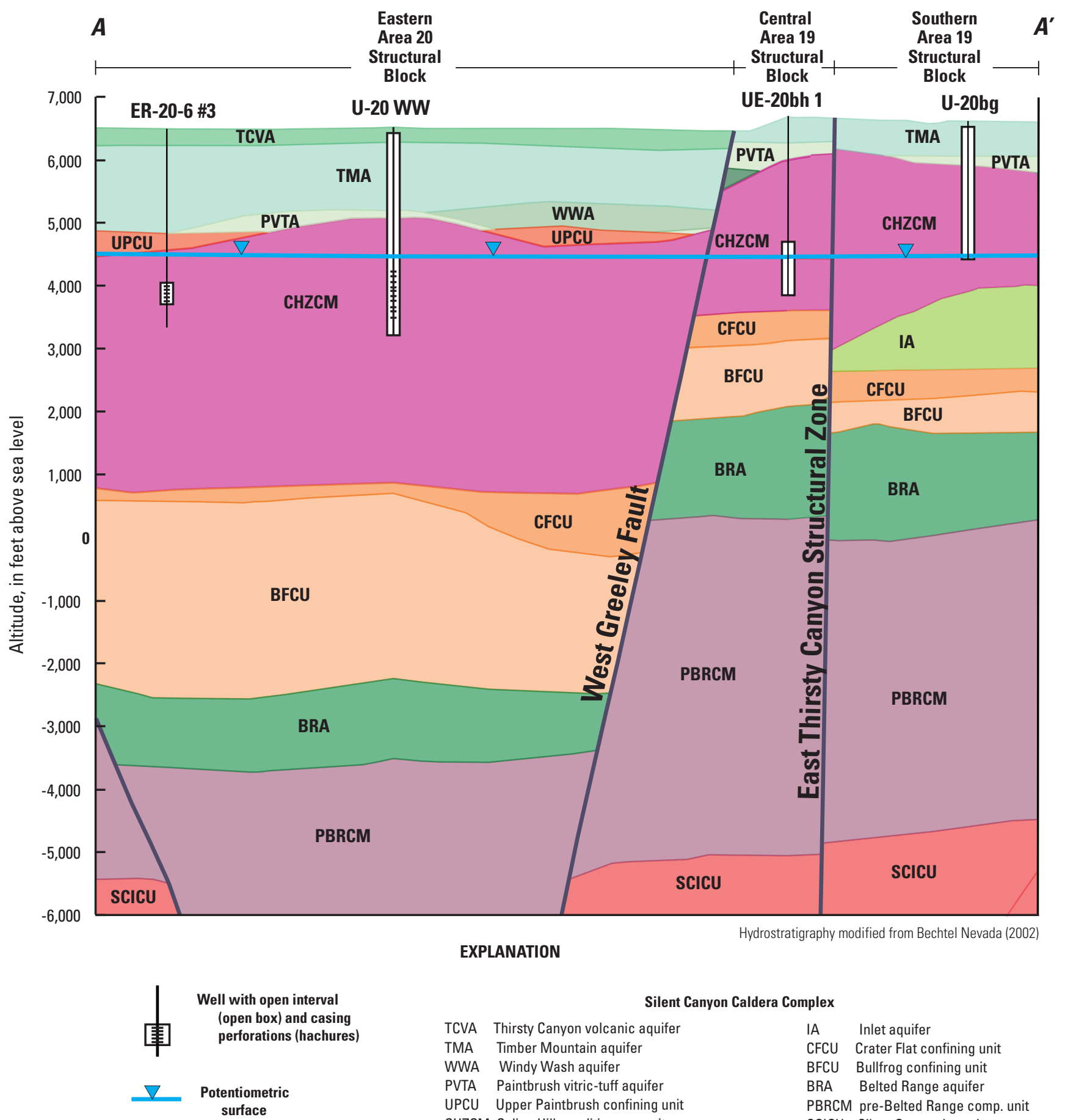

\begin{tabular}{llll}
\multicolumn{4}{c}{ Silent Canyon Caldera Complex } \\
TCVA & Thirsty Canyon volcanic aquifer & IA & Inlet aquifer \\
TMA & Timber Mountain aquifer & CFCU & Crater Flat confining unit \\
WWA & Windy Wash aquifer & BFCU & Bullfrog confining unit \\
PVTA & Paintbrush vitric-tuff aquifer & BRA & Belted Range aquifer \\
UPCU Upper Paintbrush confining unit & PBRCM pre-Belted Range comp. unit \\
CHZCM Calico Hills zeolitic composite & SCICU & Silent Canyon intrusive \\
& unit & & confining unit
\end{tabular}

Figure 2. Simplified well construction and hydrostratigraphic units at production well U-20 WW and observation wells ER-20-6 \#3, UE-20bh 1, and U-20bg, Pahute Mesa, Nevada National Security Site, Nevada. Hydrostratigraphic units above the water table are referred to as aquifers and confining units because they are saturated elsewhere on the Nevada National Security Site. 


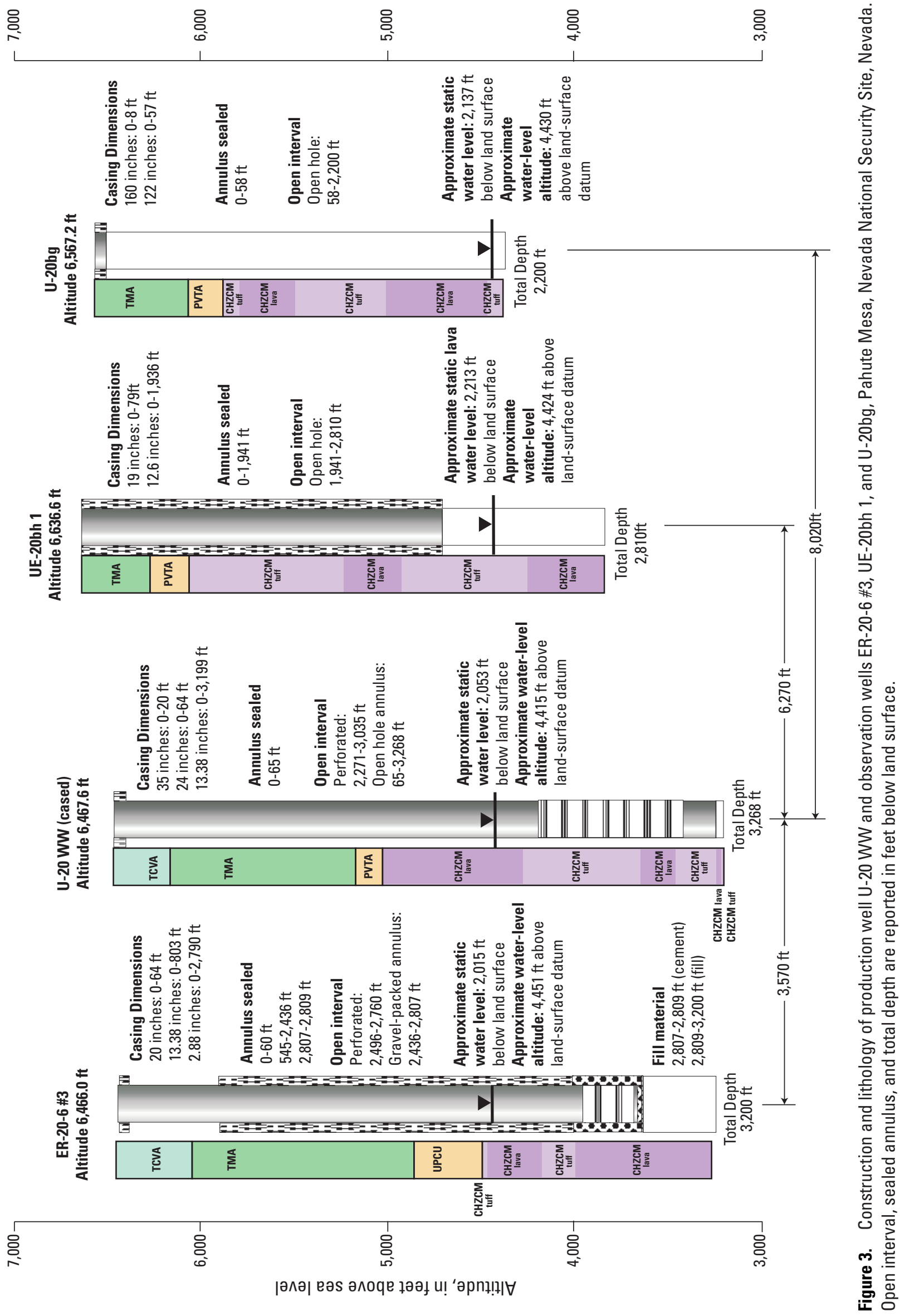


Table 1. Characteristics of wells used in U-20 WW aquifer test, Pahute Mesa, Nevada National Security Site, Nevada.

[Locations of wells are shown in figure 1. USG S site ID: Unique, 15-digit, U.S. Geological Survey site identification number. Top and B ottom Opening: Openings define area of well open to aquifer, and where, if saturated, groundwater can enter well. Open interval is open borehole and (or) well screen, including gravel pack. The opening is sometimes perforated casing (steel or pvc) and sometimes just open hole. Where multiple open intervals occur in a well, depths are to top of uppermost interval and bottom of lowermost interval. Abbreviations: NAD 27, North American Datum of 1927; ft, feet; ft bls, feet below land surface; in., inch]

\begin{tabular}{|c|c|c|c|c|c|c|c|c|c|}
\hline Well No. & USGS site ID & $\begin{array}{l}\text { Latitude } \\
\text { (NAD 27) }\end{array}$ & $\begin{array}{l}\text { Longitude } \\
\text { (NAD 27) }\end{array}$ & $\begin{array}{c}\text { Distance } \\
\text { from } \\
\text { U-20 WW } \\
\text { (ft) }\end{array}$ & $\begin{array}{c}\text { Static } \\
\text { water level } \\
\text { (ft/bls) }\end{array}$ & $\begin{array}{c}\text { Total } \\
\text { depth } \\
\text { (ft/bls) }\end{array}$ & $\begin{array}{c}\text { Top } \\
\text { opening } \\
\text { (ft/bls) }\end{array}$ & $\begin{array}{l}\text { Bottom } \\
\text { opening } \\
\text { (in.) }\end{array}$ & $\begin{array}{c}\text { Opening } \\
\text { diameter } \\
\text { (in.) }\end{array}$ \\
\hline U-20 WW & 371505116254501 & $37^{\circ} 15^{\prime} 0.5^{\prime \prime}$ & $116^{\circ} 25^{\prime} 45.4^{\prime \prime}$ & & 2,053 & 3,268 & 65 & 3,268 & 17.50 \\
\hline ER-20-6 \#3 & 371533116251801 & $37^{\circ} 15^{\prime} 33.1^{\prime \prime}$ & $116^{\circ} 25^{\prime} 17.5^{\prime \prime}$ & 3,570 & 2,015 & 3,200 & 2,436 & 2,807 & 12.25 \\
\hline U-20bg & 371414116242901 & $37^{\circ} 14^{\prime} 13.6^{\prime \prime}$ & $116^{\circ} 24^{\prime} 28.8^{\prime \prime}$ & 8,020 & 2,137 & 2,200 & 58 & 2,200 & 96.00 \\
\hline UE-20bh 1 & 371442116243301 & $37^{\circ} 14^{\prime} 41.9^{\prime \prime}$ & $116^{\circ} 24^{\prime} 33.0^{\prime \prime}$ & 6,270 & 2,213 & 2,810 & 1,941 & 2,810 & 12.25 \\
\hline
\end{tabular}

\section{Data Collection}

The weekly pumping schedule for production well U-20 WW during the aquifer test typically was about 8 hours per day, Monday through Thursday. Typical discharge rates during periods of pumping ranged from about 110 to $170 \mathrm{gal} / \mathrm{min}$. Pumping rates were limited by excessive drawdown of about $700 \mathrm{ft}$ in the screened interval of production well U-20 WW.

Pumping was distributed over three distinct pumping periods (fig. 4). The total withdrawal over these pumping periods was about 4.5 Mgal. Pumping for the first period started on October 14, 2008, at 11:30 PST and ended on December 12, 2008, at 16:00 PST (fig. 4). The cumulative discharge during this period of pumping was about $3.1 \mathrm{Mgal}$. Pumping for the second period started on June 2, 2009, at 13:00 PST and ended on June 30, 2009, at 15:00 PST, and pumping for the third period started on July 9, 2009, at 8:30 PST and ended July 27, 2009, at 13:00 PST (fig. 4). The cumulative discharge during the second and third periods was about 0.6 and $0.8 \mathrm{Mgal}$, respectively.

The production well (U-20 WW) and three observation wells were monitored from October 1, 2008, to October 1, 2009. Pumping rates were monitored continuously in the production well and water levels were measured continuously in all wells (fig. 4). These data provided the pumping, drawdown, and recovery information for this analysis.

Water-level changes in wells UE-20bh 1, U-20bg, and ER-20-6 \#3 were measured at 15-minute intervals with WaterLOG ${ }^{\circledR} \mathrm{H}-310$ pressure transducers during the monitoring period (October 1, 2008-October 1, 2009). The manufacturer-provided transducer accuracy was at least $\pm 0.007 \mathrm{ft}$. Pressure transducers periodically failed and were replaced during the measurement period (fig. 4). Water-level change in production well U-20 WW was measured from November 14, 2008, to October 1, 2009, at 2-minute intervals with a pressure transducer. The manufacturer-provided transducer accuracy was $\pm 1.12 \mathrm{ft}$ or better. All transducers were calibrated under laboratory and field conditions ( $\mathrm{La}$ Camera and others, 2005). Water temperature and barometric pressure also were measured at all well sites.

Discharge from well U-20 WW was monitored from October 14, 2008, to October 1, 2009, at 15-minute intervals with an in-line, totalizing flow meter. Accuracy of flow-meter measurements was not verified; however, a comparison between similar-type flow meters used at the NNSS and a portable acoustic-velocity flow meter indicates the data are accurate to within 10 percent of actual withdrawals (Peggy Elliott, U.S. Geological Survey, written commun., 2009).

Drawdown monitored in well U-20 WW was predominantly 600-700 ft for the period of record (in July and August, 2009 drawdown was about 450 ft) (fig. 4). Periods of greater drawdown corresponded with periods of greater short-term pumping rates.

Pumping and recovery cycles were monitored and summarized for analysis. A total of 51 pumping and recovery cycles occurred in well U-20 WW between October 1, 2008, and October 1, 2009. The authors had no control over the pumping schedule. Water levels in distant observation wells were assumed impervious to high-frequency changes in pumping; therefore, recovery periods of less than 5 days were ignored, and pumping and recovery cycles were reduced from 51 to 3 . Figure 5 shows water-level changes generated from Theis (1935) transforms (explained in more detail in the following section) of both 51 and 3 pumping and recovery cycles for radial distances of $0.3,6,270$, and $9,000 \mathrm{ft}$ from the pumping well. Excluding the pumping well (radius $=0.3 \mathrm{ft}$ ), 3 pumping and recovery cycles sufficiently approximated pumping signals when compared with 51 total cycles. Thus, three pumping and recovery cycles were considered adequate to describe the pumping signal at the three observation wells. 

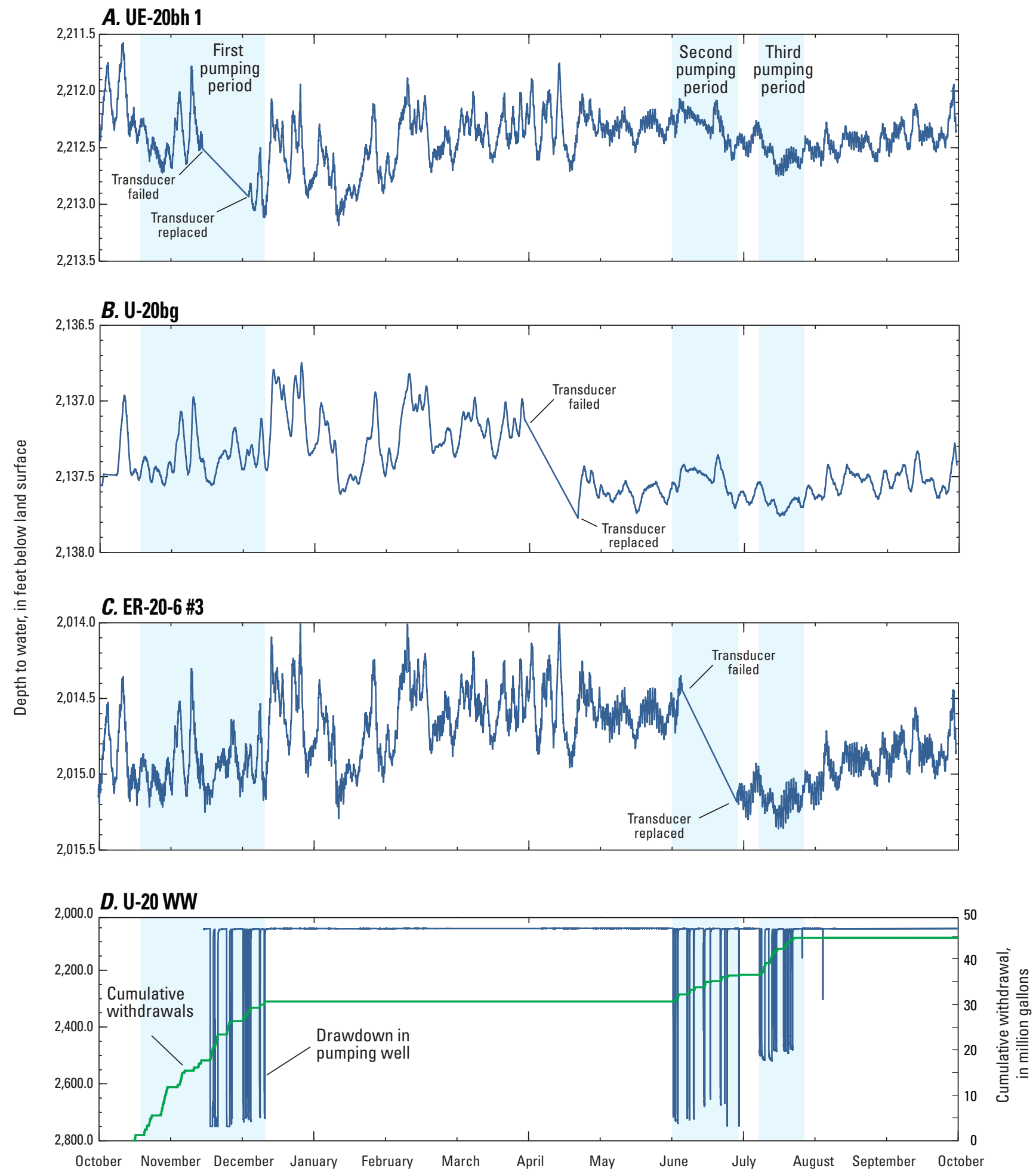

Water year 2009

Figure 4. Water-level and withdrawal data collected from U-20 WW aquifer test, Pahute Mesa, Nevada National Security Site, Nevada, October 1, 2008-0ctober 1, 2009. 

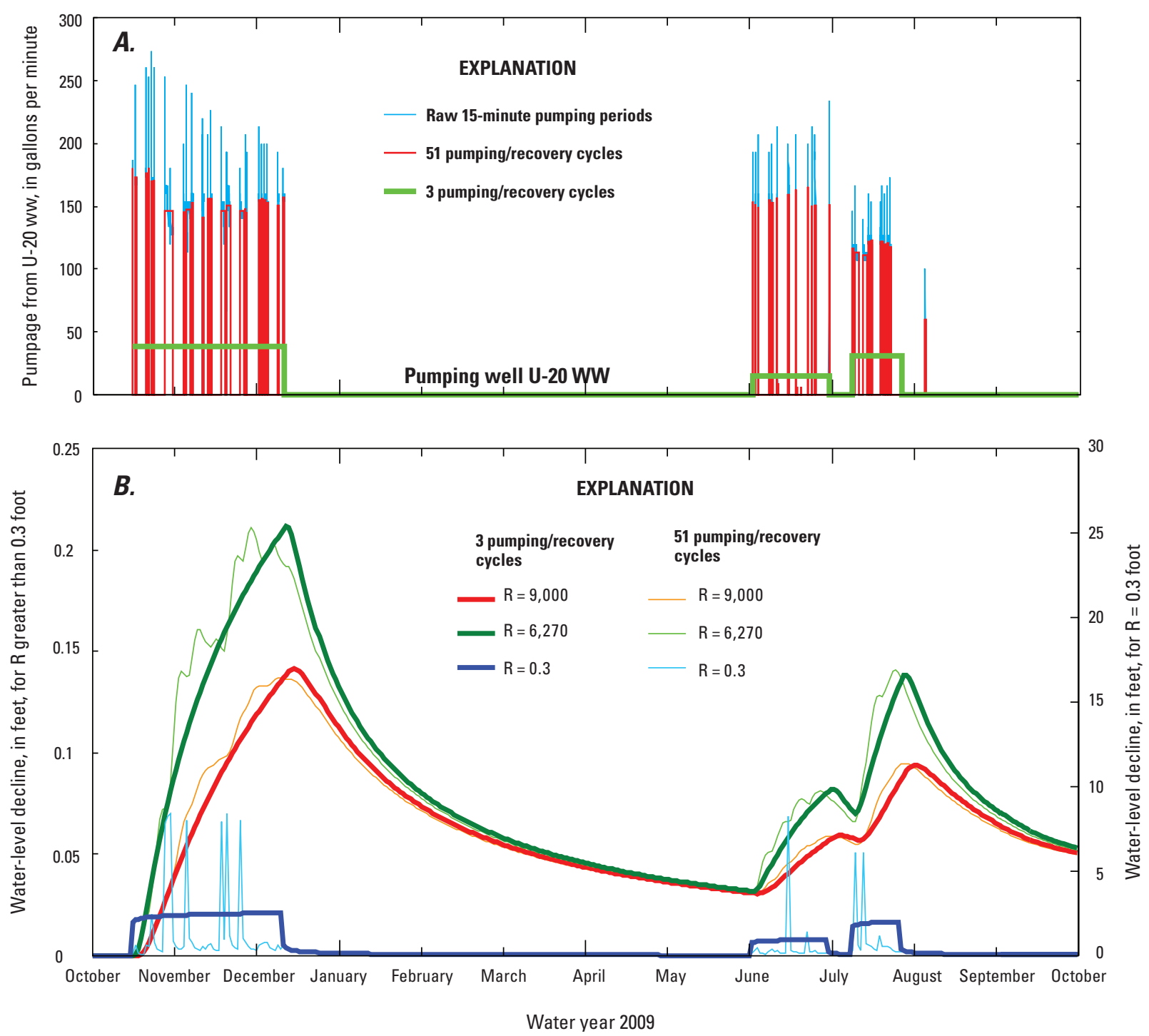

Figure 5. Pumpage from U-20 WW binned three different ways and the effect of binning on the pumping signal at three radial distances (R) from the pumping well, Pahute Mesa, Nevada National Security Site, Nevada. The pumping signal was transformed to water-level decline using a Theis (1935) solution. 


\section{Drawdown Estimation}

Water-level drawdown in observation wells resulting from pumping in well U-20 WW was estimated using measured and synthetic water levels. Synthetic water levels are developed using simple spreadsheet-based analytical models and typically represent unpumped water levels during aquifer tests. The unpumped water levels are simulated using environmental fluctuations or natural water-level changes that can be created using multiple time-series of barometric pressure change, corrections (for example, barometric efficiency), tidal potential, and background water levels (Halford, 2006a). Previous studies (Halford, 2006a; Garcia and others, 2010) used the summation of environmental fluctuations alone to create synthetic water levels. Synthetic water levels representing local, non-pumping stresses were fit to measured water levels for a period prior to pumping by automatically adjusting the amplitude and phase of the component time series. The pre-pumping relationship was then projected forward during the pumping period and the difference between measured and synthetic water levels determined the drawdown. Pumping in production well U-20 WW has been pervasive over the last 25 years (Fenelon, 2000; Elliott and Moreo, 2011) and consequently, pumping and observation wells are continually in a state of drawdown or recovery. Because those measured water levels that lacked a pumping stress were not available for the fitting process, synthetic water levels in this study were modified to represent a combination of non-pumping and pumping stresses.

\section{Synthetic Water Levels}

Synthetic water levels in this study represent both non-pumping and pumping stresses in observation wells before, during, and following the multi-well aquifer test. Environmental water-level fluctuations or non-pumping stresses were simulated with time series of barometric pressure, earth and gravity tides (Harrison, 1971; Halford, 2006a), and a step change for the period of missing record between transducer installations in observation well ER-20-6 \#3. A linear trend also was incorporated when (1) instrument drift or (2) where increasing water levels from higher-than-average long-term recharge (Elliot and Fenelon, 2010) were likely. Most of the linear trend applied to water levels is attributed to long-term recharge effects in these wells. Applied linear trends ranged from 0.3 to $1.0 \mathrm{ft} / \mathrm{yr}$.
The pumping stress in wells UE-20bh1, ER-20-6 \#3, and U-20bg was transformed into water-level change using the Theis (1935) equation. Multiple pumping periods were simulated by transforming and superimposing multiple Theis solutions. Theis transforms serve as simple transform functions, where step-wise pumping records are translated into approximate water-level responses at an observation well. The transmissivity and storage coefficient estimates are approximations used solely to transform the water-level responses and are meaningless as hydraulic-property estimates of the flow system.

Drawdown of up to $700 \mathrm{ft}$ in the pumping well likely reflects well efficiency effects; therefore, production well U-20 WW was excluded from the drawdown analysis. Generalized geology from the well log indicates that the primary contributing unit could be permeable lava underlain by low permeability bedded tuff. Geologic inferences combined with considerable drawdown imply that dewatering of the primary contributing unit likely occurred during pumping, ultimately disassociating the pumping water level from the source water. When the water table is drawn down below the permeable zone, the permeable zone is assumed to act as a seepage face. Water enters the well through the seepage face and cascades down the well casing to the water table. During pumping, an electric tape intermittently responded as it was being lowered to the water table, indicating that it was encountering this cascading water along the well casing.

Synthetic water levels (summation of environmental fluctuations and transformed pumping signals) were fit to measured water levels from April 1 to October 1, 2009, by minimizing a sum-of-squares objective function (Halford, 2006a). Amplitude and phase of each time series that simulated the environmental fluctuations were estimated. Transmissivity and storage coefficients in the Theis transforms also were estimated; although, these values have no physical significance because the underlying assumptions of the Theis solution were disregarded.

Synthetic water levels were not fit to measured water levels during the pumping and recovery cycle from October 15 to December 10, 2008, because water levels were not measured in well UE-20bh 1 during much of November 2008 (fig. 4). All three pumping periods during water year 2009, however, were interpreted because recovery from the first pumping period affected water levels during the fitting period between April 1, 2009, and October 1, 2009 (ig. 5). Prolonged recovery from the first pumping period was expected because 3.1 Mgal were pumped during the first period, which was 70 percent of the pumped water during water year 2009 (fig. 4). 
Differences between measured and simulated observations defined the goodness-of-fit or improvement of calibration. Differences between measured and synthetic water levels, or residuals, were weighted and summed in the objective function,

$$
S S(x)=\sum_{i=1}^{n o b s}\left[\left(\hat{o}_{i}-o_{i}\right) w_{i}\right]^{2},
$$

where

$x$ is the vector of parameters being estimated, nobs is the number of observations that are compared,

$\hat{o}_{i}$ is the $i^{\text {th }}$ simulated observation,

$o_{i}$ is the $i^{\text {th }}$ measurement or regularization observation, and, $w_{i}$ is the $i^{\text {th }}$ weight.

Although the sum-of-squares error serves as the objective function, root-mean-square (RMS) error was reported because RMS error was compared easily to measurements. Root-mean-square error is,

$$
R M S=\sqrt{S S / \sum_{i=1}^{\text {nobs }} w_{i}^{2}} .
$$

\section{Drawdown Analysis}

Drawdown estimates for each observation well were the summation of the Theis transform of the pumping signal and residual differences between synthetic and measured water levels. Residual differences during pumping have a distinct pattern that differs from random residuals during non-pumping periods because the Theis transform is not a perfect representation of drawdown. Therefore, residuals provide a reliable secondary signal that is correlated to the pumping signal and accounts for pumping and uncertainty that is unexplained by the Theis transform. The magnitude of the residual error between synthetic and measured water levels did not allow actual drawdowns of less than $0.1 \mathrm{ft}$ to be distinguished from the errors. Therefore, a drawdowndetection threshold of $0.1 \mathrm{ft}$ was used for the water-level modeling analysis.

Well UE-20bh 1 was the only well with a drawdown response $(0.37 \mathrm{ft}$ ) above the threshold value of $0.1 \mathrm{ft}$ (fig. 6 ). A notably greater drawdown estimate $(0.37 \mathrm{ft})$ relative to the residual differences (-0.06 to $0.08 \mathrm{ft}$, table 2$)$ or detection threshold provides confidence that the drawdown estimate is evident. Estimated drawdowns in wells U-20bg and ER-20-6 \#3 were less than the threshold-detection value (fig. $6 \mathrm{~B}$ and $\underline{6 C}$ ) and could not be distinguished from the unexplained residual error that remained after the fitting procedure (as much as $0.15 \mathrm{ft}$, table 2).

Well ER-20-6 \#3 is the observation well nearest to and within the same structural block as the pumping well, and is open to a relatively transmissive lava $\left(2,000-4,000 \mathrm{ft}^{2} / \mathrm{d}\right.$; IT Corporation, 1998), yet drawdown was less than the detection threshold. The lack of response in this well supports the CHZCM description as a mixture of aquifers and confining units and suggests that the lobes of lava penetrated by wells ER-20-6 \#3 and U-20 WW are hydraulically separated by bedded tuff.

Negligible drawdown detected in well U-20bg is likely because the well is open only to bedded tuff. The lack of response in well U-20bg also might be due to:

1. Distance from the pumping well $(1,750 \mathrm{ft}$ farther than well UE-20bh 1);

2. Well screen and aquifer intersect for less than $100 \mathrm{ft}$ at the top of the water table where signals might be dampened; and

3. The large well diameter (96 in.), which likely attenuates pumping and environmental signals alike.

The U-20bg water-level trace in figure $4 B$ appears substantially smoother than the other observation wells, despite similar collection intervals.

Table 2. Estimated drawdown in observation wells during the U-20 WW aquifer test, Pahute Mesa, Nevada National Security Site, Nevada.

[Locations of wells are shown in figure 1. E stimated drawdown: Value determined from water-level modeling. R ange of residuals: Range of residuals denotes the differences between measured and simulated water levels that were used to compute drawdown. R M S error: Unweighted rootmean-square error describing fit between measured and synthetic water levels. $<$, less than; $\mathrm{ft}$, feet]

\begin{tabular}{lccc}
\hline Well No. & $\begin{array}{c}\text { Estimated } \\
\text { drawdown } \\
\text { (ft) }\end{array}$ & $\begin{array}{c}\text { Range of } \\
\text { residuals } \\
\text { (ft) }\end{array}$ & $\begin{array}{c}\text { RMS error (ft) } \\
\text { (drawdown } \\
\text { estimation) }\end{array}$ \\
\hline UE-20bh 1 & 0.37 & $-0.06-0.08$ & 0.02 \\
U-20bg & $<0.1$ & $-0.1-0.05$ & 0.02 \\
ER-20-6 \#3 & $<0.1$ & $-0.1-0.15$ & 0.04 \\
\hline
\end{tabular}



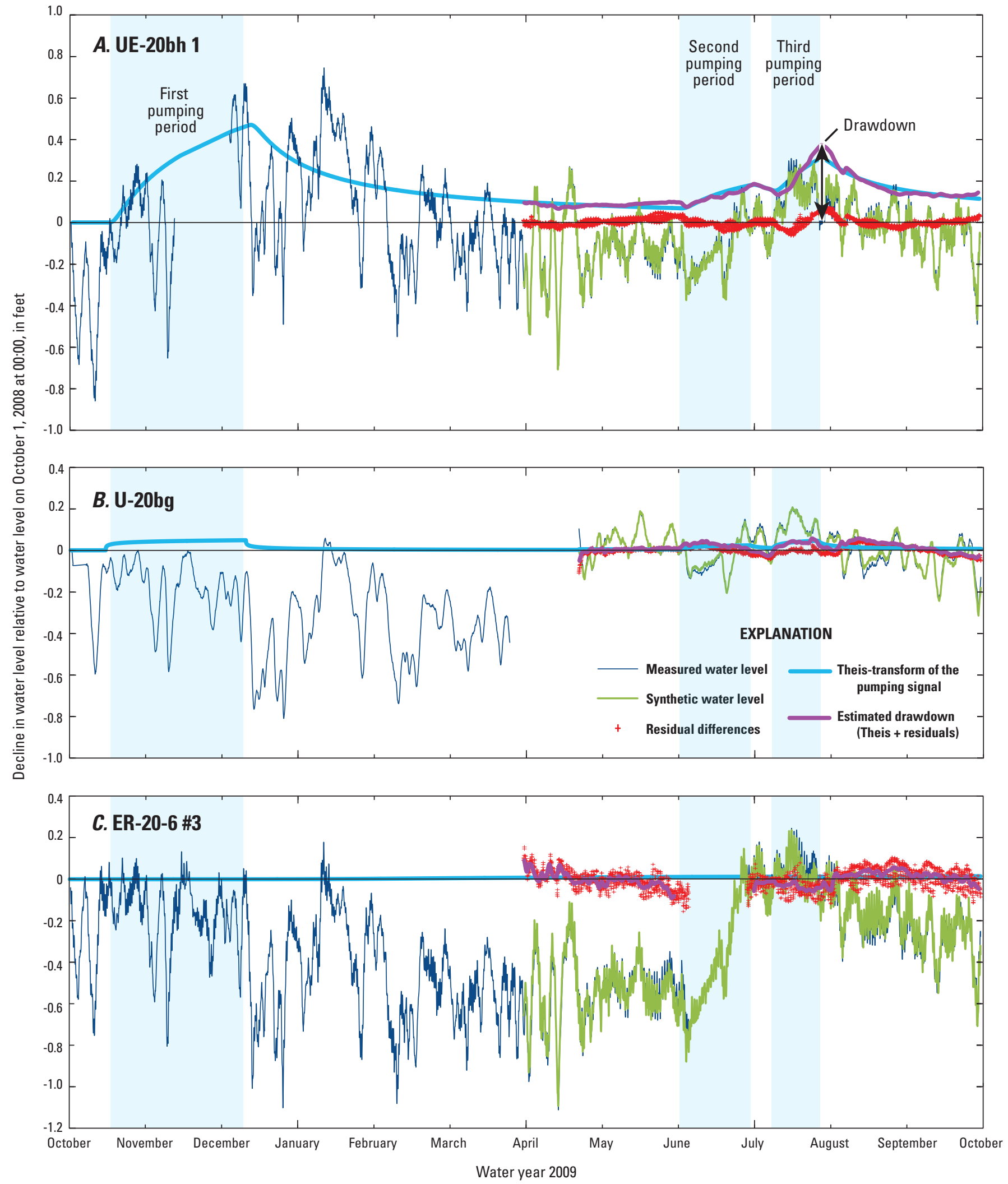

Figure 6. Measured, synthetic, and residual water levels, a Theis transform of the pumping response, and estimated drawdown in observation wells $(A)$ UE-20bh 1, $(B)$ U-20bg, and $(C)$ ER-20-6 \#3, Pahute Mesa, Nevada National Security Site, Nevada. Water levels were measured from October 1, 2008, to October 1, 2009, but drawdown was only analyzed from April 1 to 0 ctober 1, 2009. Residual data represent measured water-level changes that were not explained by environmental fluctuations or the Theis transform. 


\section{Numerical Aquifer Test Analysis}

In the numerical aquifer-test analysis, hydraulic properties of CHZCM aquifer and confining units were estimated with a numerical model using drawdown estimates from the three observation wells. The hydrogeologic framework for the CHZCM was conceptualized from discrete blocks of aquifer and confining unit corresponding to lavas and bedded tuffs, respectively. Transmissivity, specific yield, and specific storage of lavas and bedded tuffs were estimated with the numerical model, which was solved with MODFLOW (McDonald and Harbaugh, 1988; Harbaugh and McDonald, 1996). A sensitivity analysis was performed to evaluate the hydraulic significance of the West Greeley Fault (WGF) that separates production well U-20 WW from observation wells UE-20bh1 and U-20bg.

The three-dimensional MODFLOW model was developed to:

1. Estimate the hydraulic properties of the lavas and bedded tuffs within the CHZCM;

2. Explain the undetected pumping response at well ER-20-6

3. Refine the hydrogeologic framework of the CHZCM;

4. Evaluate the hydraulic significance of the West Greeley fault.

A line of symmetry perpendicular to the WGF was assumed to bisect well U-20 WW so that only half of the area of interest was simulated (fig. 1). Wells south of this line of symmetry (wells UE-20bh 1 and U-20bg) were projected into the model area (fig. 1).

The lithologic units in the CHZCM were conceptualized from lithologic logs of the pumping and observation wells (fig. 3; Wood, 2009). The major fault structure was initially simulated by simply displacing lithologic units, therefore assuming that the fault and host rock share similar hydraulic properties. Rocks below the water table in the model were divided into five units (fig. 7):

1. A 250-ft upper layer of lava that supplies water to U-20 WW and truncates at the WGF;

2. A 750-ft lobe of lava that surrounds ER-20-6 \#3, but is not hydraulically connected with U-20 WW and does not extend east to the WGF;

3. A 900-ft layer of lava east of the WGF that supplies water to UE-20bh 1;

4. A 950-ft bedded tuff west of the WGF, and

5. A 200-ft upper layer of bedded tuff east of the WGF that supplies water to U-20bg.
As previous hydrologic framework studies indicate, lava generally is more productive than tuff (Blankennagel and Weir, 1973; Laczniak and others, 1996; Prothro and Drellack, 1997). The upper layer of lava, which is present at the water table (fig. 3 ), was assumed to provide most of the water to well U-20 WW, whereas minimal contributions were assumed for the underlying tuff. The thickness of the upper lava unit is arbitrary because transmissivity, the product of hydraulic conductivity and thickness, remains constant.

The model domain was discretized into 13 layers of 57 rows and 153 columns (fig. 7). The model grid extended laterally about 200,000 ft away from well U-20 WW, and vertically from the water table to $1,200 \mathrm{ft}$ below. Rows and columns were assigned widths of $0.2 \mathrm{ft}$ near well U-20 WW. Row and column widths were multiplied by 1.25 from near well U-20 WW to the edges of the model. Layer thicknesses ranged from $1 \mathrm{ft}$ at the water table to $650 \mathrm{ft}$ at the base of the model; most layers were $50 \mathrm{ft}$ thick (fig. 7). All external boundaries were no-flow because the lateral extension of the model grid is essentially infinity. Changes in the saturated thickness of the aquifer were not simulated because the maximum drawdown near the water table was small relative to the total thickness. The U-20 WW aquifer test was simulated from October 1, 2008, to October 1, 2009, with six stress periods, which included three pumping and three recovery periods (fig. 5).

Hydraulic properties were estimated by minimizing differences between simulated and estimated drawdown in observation wells (Halford, 2006b). Observations consist of estimated drawdowns, which are the summation of the Theis transform of the pumping signal and the residual differences between synthetic and measured water levels (ig. 6). The large drawdown in the pumping well was not simulated and compared because it is more indicative of well-efficiency effects rather than gross aquifer properties.

\section{Simulated Drawdown}

Simulated and estimated drawdown matched with an RMS error of $0.03 \mathrm{ft}$ (fig. 8). A drawdown of $0.3 \mathrm{ft}$ was simulated for well UE-20bh 1 (east of the WGF), whereas simulated drawdown did not exceed $0.02 \mathrm{ft}$ in observation wells U-20bg (east of WGF) and ER-20-6 \#3 (west of WGF) (table 3). Measureable drawdown was simulated in well UE-20bh1 because contiguous lavas were interpreted between the pumping well and well UE-20bh 1 . Inferred, lowpermeability tuffs isolated wells U-20bg and ER-20-6 \#3 from the effects of pumping well U-20 WW (west of WGF). 


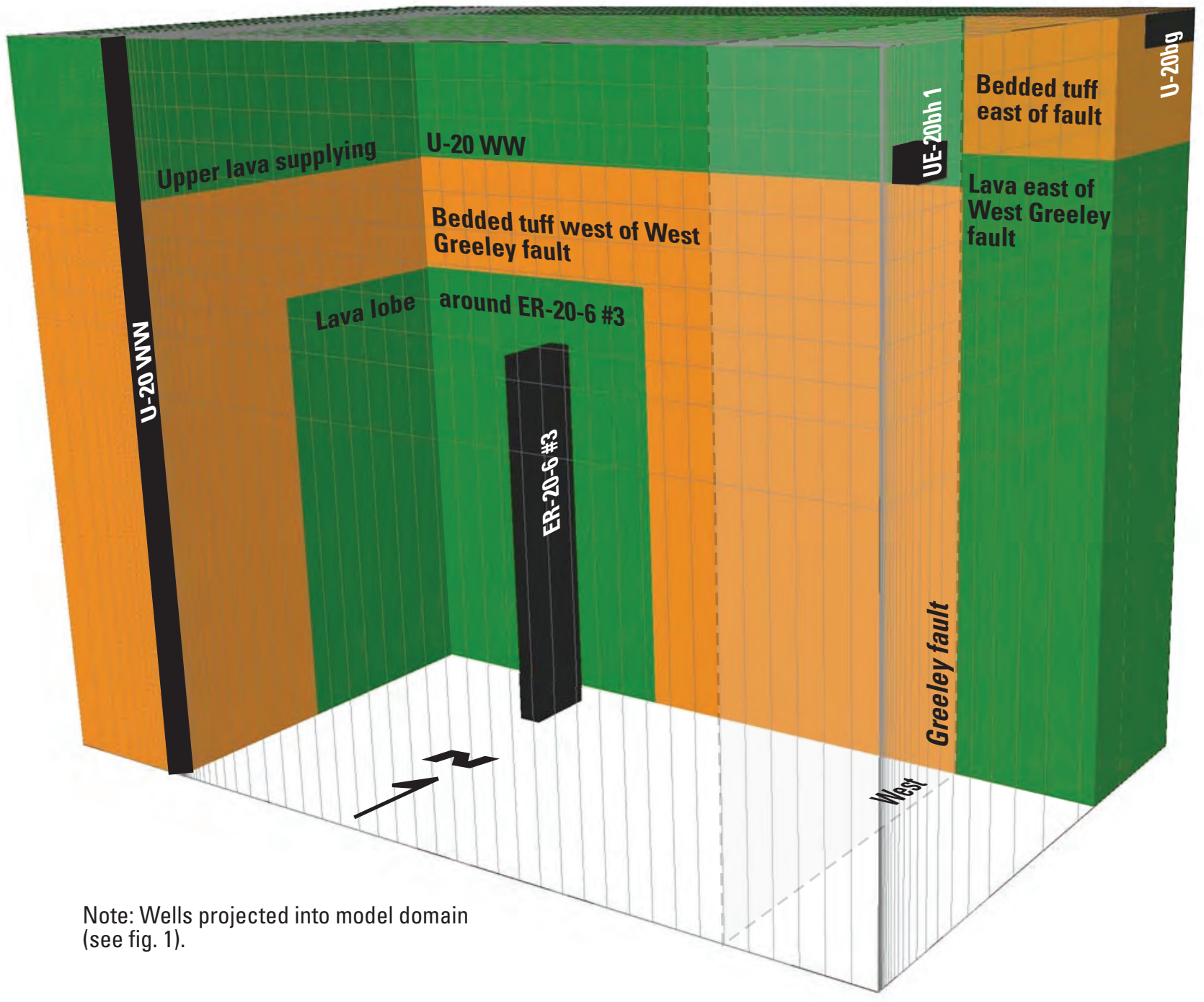

Figure 7. Model layering and lithologic unit intervals in numerical flow model used to simulate pumping response in production well U-20 WW, Pahute Mesa, Nevada National Security Site, Nevada. The upper-most layer represents the water table. 

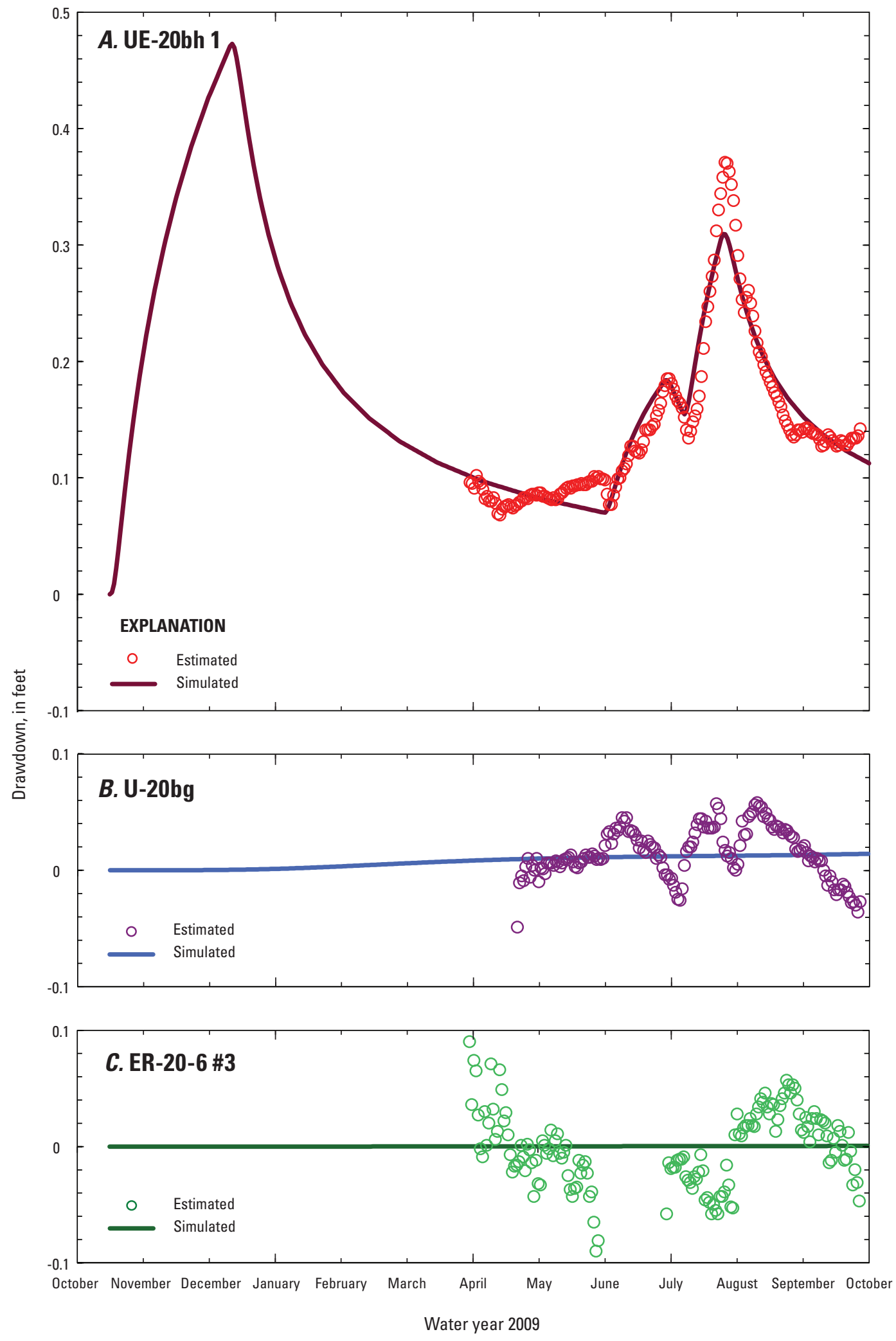

Figure 8. Comparison of simulated and estimated drawdown data for observation wells used in the numerical flow model, Pahute Mesa, Nevada National Security Site, Nevada. Estimated drawdown is the summation of residual differences between synthetic and measured water levels and Theis transform of the pumping signal. 
Table 3. Comparison between simulated and estimated drawdown in observation wells during the U-20 WW aquifer test, Pahute Mesa, Nevada National Security Site, Nevada.

[Locations of wells are shown in figure 1. Simulated drawdown: value simulated with numerical MODFLOW model. Estimated drawdown: numerical observations determined from synthetic water levels. R M S error: unweighted root-mean-square error describing fit between simulated and estimated drawdowns; <, less than. Abbreviations: ft, foot]

\begin{tabular}{|c|c|c|c|}
\hline \multirow{2}{*}{ Well No. } & \multicolumn{2}{|c|}{ Drawdown (ft) } & \multirow{2}{*}{$\begin{array}{c}\text { RMS error (ft) } \\
\text { (numerical MODFLOW } \\
\text { modeling) }\end{array}$} \\
\hline & Simulated & Estimated & \\
\hline UE-20bh 1 & 0.3 & 0.37 & 0.02 \\
\hline U-20bg & $<0.02$ & $<0.1$ & 0.02 \\
\hline ER-20-6 \#3 & $<0.02$ & $<0.1$ & 0.03 \\
\hline
\end{tabular}

Simulated drawdown at the end of the third pumping period is shown in figure 9. A drawdown threshold of $0.1 \mathrm{ft}$ reasonably defines the investigated aquifer volume and is supported by the drawdown-detection threshold $(0.1 \mathrm{ft})$ and overall RMS error $(0.03 \mathrm{ft})$ for the numerical model. This defined volume can be interpreted as the minimum investigated volume where drawdown estimates exceed $0.1 \mathrm{ft}$. Drawdown propagated primarily through the permeable lavas and diffused into the less permeable bedded tuffs (ig. 9). Simulated drawdown extended across the WGF because permeable lavas are not hydraulically isolated by fault displacement of structural blocks. Drawdown is vertically constrained just west of the WGF by a less permeable bedded tuff that isolates the lava-supplying well ER-20-6 \#3. Drawdown also is constrained east of the WGF by a bedded tuff intersecting the water table and well U-20bg.

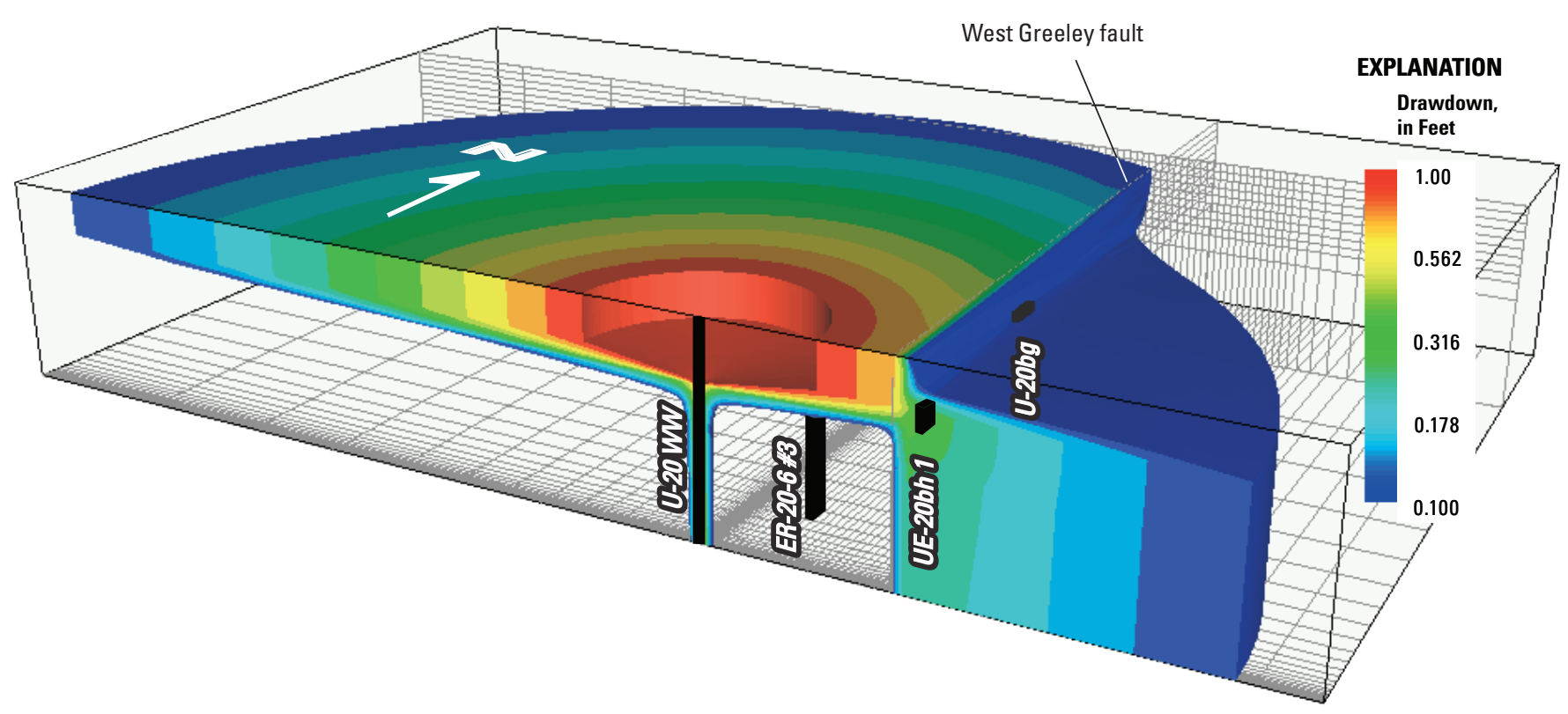

Figure 9. Drawdown cone at the end of the third pumping period (day 285) in numerical flow model, Pahute Mesa, Nevada National Security Site, Nevada. Cone is truncated at $0.1 \mathrm{ft}$ of drawdown. 


\section{Hydraulic-Property Estimates}

Hydraulic properties of the volcanic-rock units making up the CHZCM were defined in the numerical flow model using six parameters:

1. Horizontal hydraulic conductivity of lava (all units were assumed equal);

2. Horizontal hydraulic conductivity of bedded tuff west of WGF;

3. Horizontal hydraulic conductivity of bedded tuff west of WGF;

4. Specific yield of bedded tuff, where it lies at the water table, east of WGF;

5. Specific storage of all units; and

6. All units within the CHZCM were assumed isotropic from the water table to the base of the model (Pawloski and others, 2001).

Three hydraulic conductivities, a specific yield, and a specific storage were estimated during model calibration. A vertical-to-horizontal anisotropy of 1.0 was assigned and not estimated because vertical-to-horizontal anisotropy and specific yield are highly correlated. A specific yield was not assigned west of the WGF because the upper lava supplying well U-20 WW was assumed confined as the pumping signal propagated through the aquifer system at distances of more than $1 \mathrm{mi}$.

The estimated transmissivity of lava supplying water to $\mathrm{U}-20 \mathrm{WW}$ is $1,200 \mathrm{ft}^{2} / \mathrm{d}$ (table 4). The transmissivity of the lava east of the WGF that is hydraulically connected to the lava supplying U-20 WW was estimated to be $3,400 \mathrm{ft}^{2} / \mathrm{d}$. Transmissivity estimates for the lava lobe around ER-20-6 \#3 and tuff units are highly uncertain because of poorly constrained estimates of drawdown in wells ER-20-6 \#3 and U-20bg. However, transmissivities for the bedded tuffs can be considered upper bounds because the estimated drawdowns in wells ER-20-6 \#3 and U-20bg that were compared to simulated drawdowns are maximum estimates. Estimated transmissivity and specific storage values of $3,600 \mathrm{ft}^{2} / \mathrm{d}$ and $2.1 \times 10^{-6} 1 / \mathrm{ft}$ for the lava lobe around well ER-20-6 \#3 are reasonable and similar to previous estimates of 2,000-4,000 ft $2 / \mathrm{d}$ and $2.5 \times 10^{-7}-1 \times 10^{-6} 1 / \mathrm{ft}$, respectively (IT Corporation, 1998). Transmissivities in bedded tuff units of less than $0.2 \mathrm{ft}^{2} / \mathrm{d}$ and the low specific yield value of $<0.03$ in the tuff east of the WGF are representative of confining units (Kruseman and deRidder, 1990). Estimated hydraulic conductivities of the lavas and tuffs differ by more than 3 orders of magnitude. This suggests that lavas should be differentiated from tuffs to simulate flow through the CHZCM.

Table 4. Hydraulic properties of lithologic units simulated in the numerical flow model for well U-20 WW, Pahute Mesa, Nevada National Security Site, Nevada.

[Vertical-to-horizontal anisotropy: Values assigned, not estimated. A bbreviations: $\mathrm{ft}$, feet; $\mathrm{ft} / \mathrm{d}$, feet per day; $\mathrm{ft}^{2} / \mathrm{d}$, feet squared per day. <, less than]

\begin{tabular}{|c|c|c|c|c|c|}
\hline Simulated lithologic units & $\begin{array}{l}\text { Horizontal } \\
\text { hydraulic } \\
\text { conductivity } \\
\text { (ft/d) }\end{array}$ & $\begin{array}{c}\text { Thickness } \\
\text { (ft) }\end{array}$ & $\begin{array}{c}\text { Transmissivity } \\
\left(\mathrm{ft}^{2} / \mathrm{d}\right)\end{array}$ & Storage & $\begin{array}{c}\text { Vertical-to-horizontal } \\
\text { anisotropy } \\
\text { (dimensionless) }\end{array}$ \\
\hline Upper lava supplying U-20 WW & 4.8 & 250 & 1,200 & ${ }^{1} 2.1 \times 10^{-6}$ & 1.0 \\
\hline Lava east of West Greeley fault & 4.8 & 700 & 3,400 & ${ }^{1} 2.1 \times 10^{-6}$ & 1.0 \\
\hline Lava lobe around ER-20-6 \#3 & 4.8 & 750 & 3,600 & ${ }^{1} 2.1 \times 10^{-6}$ & 1.0 \\
\hline Bedded tuff west of West Greeley fault & $<0.001$ & 950 & $<0.2$ & ${ }^{1} 2.1 \times 10^{-6}$ & 1.0 \\
\hline
\end{tabular}

\footnotetext{
${ }^{1}$ Specific storage $(1 / \mathrm{ft})$.

${ }^{2}$ Specific yield (dimensionless).
} 


\section{Alternative Fault Interpretation}

The WGF was alternatively interpreted as a unique hydrologic structure using the aquifer test data. This was prompted by a previous interpretation which characterized the WGF as a flow conduit that greatly affects simulated contaminant transport beneath Pahute Mesa (Stollar-Navarro Joint Venture, 2009). The fault was simulated as a $400 \mathrm{ft}$ thick zone straddling the simplified, vertical West Greeley fault (fig. 7) and spanning two 200-ft wide columns. Two additional 0.01 -ft wide columns were added to cap the simulated fault and minimize the effects of harmonic-mean weighting on hydraulic conductivity estimates.

Hydraulic significance of the WGF was evaluated by specifying the fault hydraulic conductivity and estimating the lava hydraulic conductivity. This approach was used because hydraulic conductivities of the fault and lava were highly correlated. Specified fault hydraulic conductivities ranged between 0.01 and 1,000 ft/d and were evaluated at order of magnitude increments. The unweighted RMS error for well UE-20bh 1 and lava hydraulic conductivity were plotted as functions of fault hydraulic conductivity (ig. 10). Calibrated estimates of bedded tuff hydraulic conductivity, specific yield, and specific storage were not estimated because simulated drawdown was relatively insensitive to these hydraulic properties (table 4).

The RMS error describing the fit between estimated and simulated drawdown was lowest as the fault conductivity approached values similar to those previously estimated for lava (fig. 10). Fault conductivities between 1 and $10 \mathrm{ft} / \mathrm{d}$ corresponded with the lowest RMS errors ( 0.021 on average). Hydraulic conductivity of the lava ranged from about 2-5 ft/d as fault conductivity ranged more than 6 orders of magnitude, with a best fit of $5 \mathrm{ft} / \mathrm{d}$. These results indicate that the hydraulic conductivity of the WGF is similar to that of the permeable host rock. Therefore, the WGF neither impedes nor intercepts flow between permeable lavas, but rather brings separate structural blocks into contact.
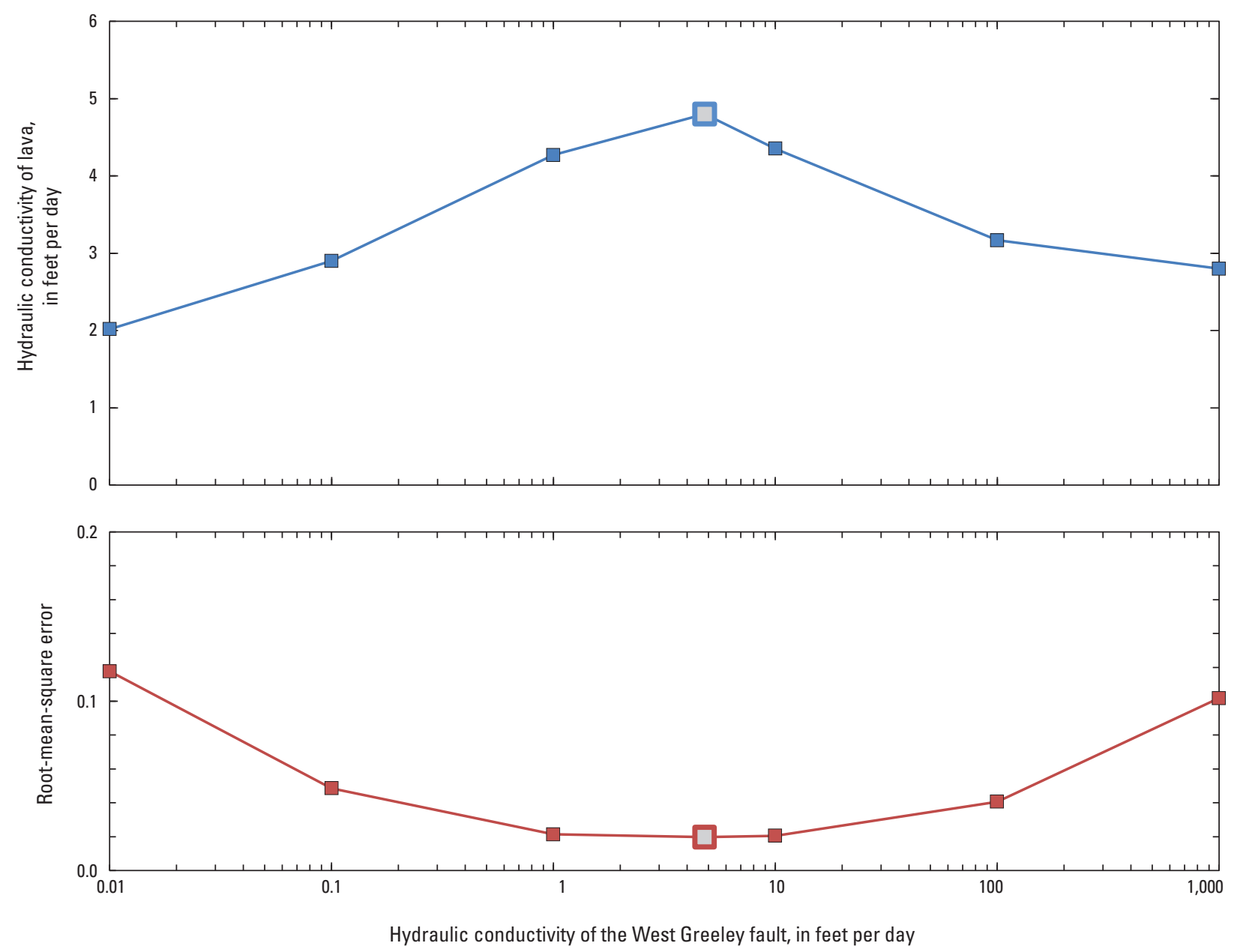

Figure 10. Comparison of West Greeley fault hydraulic conductivity with $(A)$ simulated lava hydraulic conductivity and $(B)$ numerical model unweighted root-mean-square error in well UE-20bh 1, Pahute Mesa, Nevada National Security Site, Nevada. Hydraulic conductivities of all lava units in figure 7 were assumed equal. 
Hydraulic conductivity of the WGF can range from 0.3 to $30 \mathrm{ft} / \mathrm{d}$ while adequately simulating drawdown in well UE-20bh1. Simulated drawdown in well UE-20bh1 is similar for WGF conductivities between 1 and $10 \mathrm{ft} / \mathrm{d}$ (fig. 11). Deviations between simulated and estimated drawdown are most notable for WGF hydraulic conductivities less than 0.3 and greater than $30 \mathrm{ft} / \mathrm{d}$ (fig. 11). These deviations correspond with an unweighted RMS error in well UE-20bh1 of $0.04 \mathrm{ft}$, which is twice the calibrated error.

Characterizing the WGF as a unique, highly permeable hydraulic structure through this limited subsurface view is unwarranted. The fault has limited capacity as a conduit because the hydraulic conductivity must be less than $100 \mathrm{ft} / \mathrm{d}$ to adequately explain the drawdown observed in well UE-20bh 1 (fig. 10). The assumed hydraulic conductivity range of the WGF minimally affected hydraulic conductivity estimates of the lava; lava conductivities differed by less than a factor of two while WGF values changed more than four orders of magnitude (fig. 10). This is because the simulated fault thickness of $400 \mathrm{ft}$, which can likely be viewed as an upper bound, represents less than 10 percent of the distance between the pumping well and observation well UE-20bh 1.

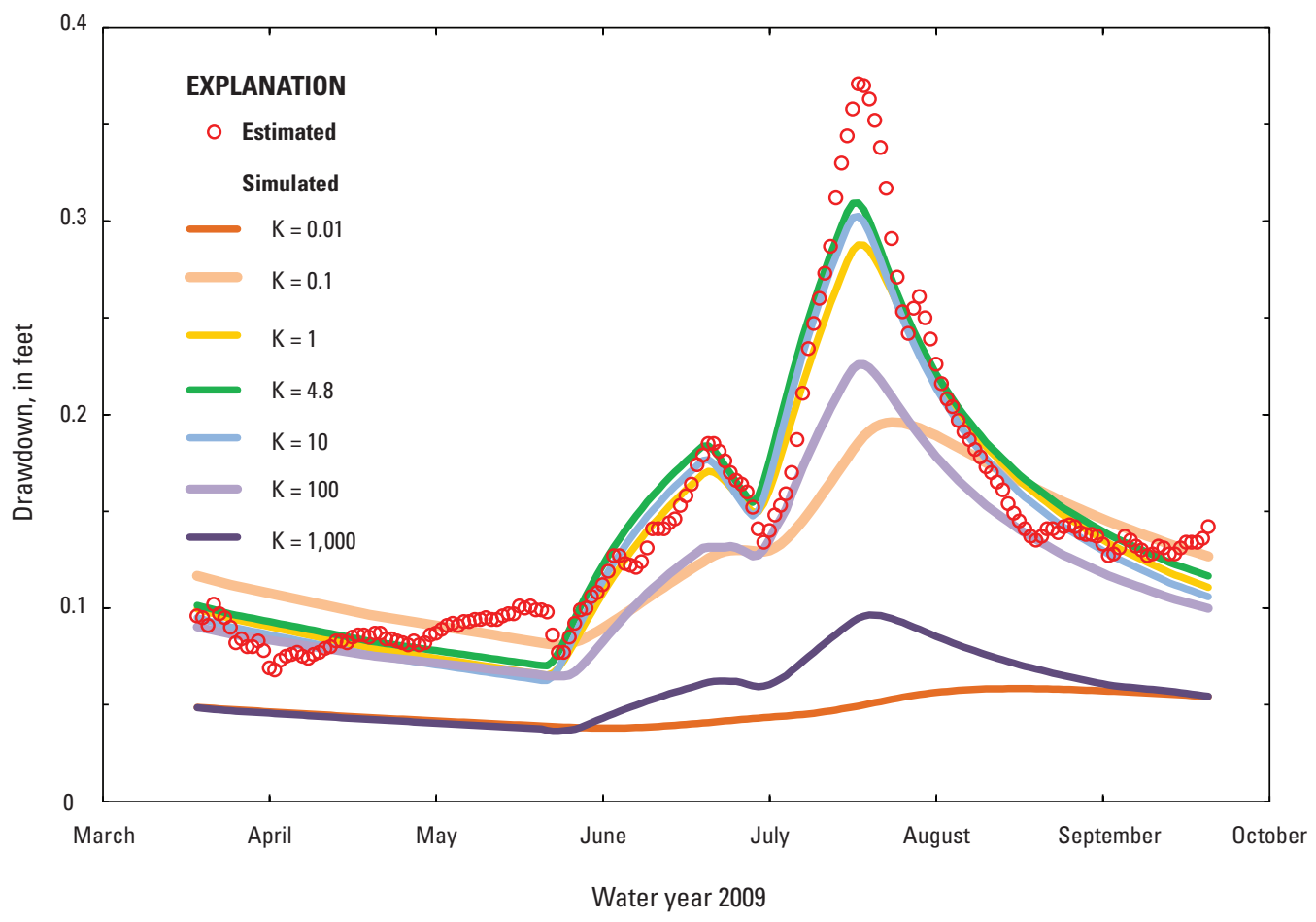

Figure 11. Comparison of simulated and estimated drawdown in well UE-20bh 1 as West Greeley fault hydraulic conductivity (K) varied between 0.01 and 1,000 ft/d, Pahute Mesa, Nevada National Security Site, Nevada. 


\section{Summary and Conclusions}

Hydraulic connections across structural blocks in Pahute Mesa were tested opportunistically. Pumping of production well U-20 WW for drilling support in western Pahute Mesa, as well as continuous monitoring of surrounding observation wells, provided the opportunity to analyze drawdown in a complex system. Interpretations of hydraulic connections across structural blocks, bulk hydraulic properties of underlying volcanic rocks, and the hydraulic significance of a major fault were attainable because measureable drawdown was detected across the West Greeley fault (WGF) in well UE-20bh1.

Periodic pumping of production well U-20 WW and observation wells ER-20-6 \#3, UE-20bh 1, and U-20bg were monitored from October 1, 2008, to October 1, 2009. All wells are completed in the Calico Hills zeolitic composite unit (CHZCM), which is comprised of volcanic rock aquifers (primarily lavas) and bedded and nonwelded tuff confining units. Observation wells UE-20bh 1 and U-20bg are structurally separated from the pumping well by the WGF whereas well ER-20-6 \#3 penetrates the same structural block as well U-20 WW.

Water-level drawdown resulting from pumping of well U-20 WW was estimated using measured and synthetic water levels in observation wells. Synthetic water levels were generated using a combination of environmental fluctuations and a Theis transform of the pumping signal. Environmental water-level fluctuations represent the summation of multiple time series of barometric pressure, earth and gravity tides, a step change for periods of missing record, and linear trends to account for instrument drift and long-term recharge. Pumping responses in observation wells were generated with a Theis transform of the pumping signal, where multiple pumping periods were simulated by transforming and superimposing multiple Theis (1935) solutions. Drawdown estimates in each observation well were the summation of the Theis transform and residual differences between synthetic and measured water levels.

A maximum water-level drawdown of 0.37 foot was detected across a major fault in well UE-20bh 1, which is more than 1 mile from the pumping well. Drawdown estimates in wells U-20bg and ER-20-6 \#3 were less than the detection threshold (less than 0.1 foot) and indistinguishable from the unexplained residual error. The lack of measureable drawdown in well ER-20-6 \#3-which is within the same structural block and nearest to the pumping well, and was previously estimated to be completed in a fairly transmissive lava_-indicates that the lava units intersecting this well and the pumping well are likely distinct and separated by a bedded tuff confining unit.

Drawdown estimates were analyzed with a numerical three-dimensional MODFLOW model to

1. Estimate the hydraulic properties of the volcanic units within the CHZCM;

2. Explain the small or nonexistent pumping response observed at well ER-20-6 \#3;

3. Refine the hydrogeologic framework of the CHZCM; and

4. Evaluate the hydraulic significance of the WGF.

Numerical separation of lavas intersecting well ER-20-6 \#3 and the pumping well with bedded tuff yielded a good fit between simulated and estimated drawdowns, with RMS errors ranging from 0.02 to 0.03 . Simulated transmissivities of the lava coincident with U-20 WW and the hydraulically connected lava east of the WGF penetrated by well UE-20bh 1 were 1,200 and 3,400 feet squared per day, respectively. Simulated transmissivities for lava around well ER-20-6 \#3 and in the bedded tuffs (3,600 and $<0.2$ foot squared per day, respectively) are uncertain because of poorly constrained estimates of drawdown in wells ER-20-6 \#3 and U-20bg. Although uncertain from aquifer-test data herein, the simulated lava transmissivity surrounding well ER-20-6 \#3 is reasonable when compared with previous estimates. Bedded tuff transmissivities can be considered upper bounds because the estimated drawdowns in wells ER-20-6 \#3 and U-20bg that were compared to simulated drawdowns are maximum estimates. The large difference between lava and bedded tuff transmissivities suggests that lavas should be differentiated from tuffs to simulate flow through the CHZCM.

Measureable drawdown in well UE-20bh 1 implies that the WGF is neither an impermeable barrier nor a highly permeable conduit that intercepts flow between structural blocks. Characterizing the WGF as a unique, highly permeable hydraulic structure is unwarranted because the hydraulic conductivity must be less than 100 feet per day. A sensitivity analysis evaluating the hydraulic significance of the WGF indicates that simulated and estimated drawdown in well UE-20bh1are adequately matched when hydraulic conductivities of the WGF range between about 0.3 and 30 feet per day; the best numerical fit was achieved when lava and WGF hydraulic conductivities were similar (5 and 1-10 feet per day, respectively). Results provide a valuable constraint on plausible fault properties and indicate that the WGF hydraulically connects, rather than intercepts, flow between structural blocks. 


\section{Acknowledgments}

The authors gratefully acknowledge National Security Technologies, LLC, for installing a flow meter on well U-20 WW; Terry L. Miller and Glenn L. Locke (USGS) for assisting with data collection; and Gregory J. Ruskauff (Navarro-Intera, LLC), Lester J. Williams (USGS), and Steven F. Carle and Gayle A. Pawloski (Lawrence Livermore National Laboratory) for helpful review comments. The U.S. Department of Energy, National Nuclear Security Administration, Nevada Site Office, Office of Environmental Management supported this work under Interagency Agreement DE-A152-07NA28100.

\section{References Cited}

Bechtel Nevada, 2002, A hydrostratigraphic model and alternatives for the groundwater flow and contaminant transport model of Corrective Action Units 101 and 102Central and western Pahute Mesa, Nye County, Nevada: U.S. Department of Energy Report DOE/NV/11718-706, $383 \mathrm{p}$.

Blankennagen, R.K., and Weir, J.E., Jr., 1973, Geohydrology of the eastern part of Pahute Mesa, Nevada Test Site, Nye County, NV: U.S. Geological Survey Professional Paper 712-B, 35 p. (Also available at http://pubs.usgs.gov/ pp/0712b/report.pdf.)

Boyd, O.S., Wagoner, J.L., and Carlson, R.C., 1992, Site characterization report for HRMP monitoring well UE20bh-1, Nye County, Nevada Test Site: Lawrence Livermore National Laboratory, 97 p.

Caine, J.S., and Forster, C.B., 1999, Fault zone architecture and fluid flow-Insights from field data and numerical modeling, in Haneberg, W.C., Mozley, P.S., Moore, J.C., and Goodwin, L.B., eds., Faults and subsurface fluid flow in the shallow crust: American Geophysical Union Monograph, v. 113, p. 101-127.

Elliot, P.E., and Fenelon, J.M., 2010, Database of groundwater levels and hydrograph descriptions for the Nevada Test Site area, Nye County, Nevada, 1941-2010: U.S. Geological Survey Data Series 533, 16 p. (Also available at http://pubs. usgs.gov/ds/533/.)

Elliott, P.E., and Moreo, M.T., 2011, Groundwater withdrawals and associated well descriptions for the Nevada National Security Site, Nye County, Nevada, 1951-2008: U.S. Geological Survey Data Series 567, 126 p.

Faunt, C.C., 1997, Effect of faulting on ground-water movement in the Death Valley Region, Nevada and California: U.S. Geological Survey Water-Resources Investigations Report 95-4132, 42 p. (Also available at http://pubs.er.usgs.gov/djvu/WRI/wrir 95 4132.djvu.)
Fenelon, J.M., Sweetkind, D.S., and Laczniak, R.J., 2010, Groundwater flow systems at the Nevada Test Site, Nevada —a synthesis of potentiometric contours, hydrostratigraphy, and geologic structures: U.S. Geological Survey Professional Paper 1771, 54 p. (Also available at http://pubs.usgs.gov/pp/1771/.)

Fenelon, J.M., 2000, Quality assurance and analysis of water levels in wells on Pahute Mesa and vicinity, Nevada Test Site, Nye County, Nevada: U.S. Geological Survey WaterResources Investigations Report 00-4014, 68 p. (Also available at http://pubs.usgs.gov/wri/WRIR00-4014/.)

Garcia, C.A., Halford, K.J., and Laczniak, R.J., 2010, Interpretation of flow logs from Nevada Test Site boreholes to estimate hydraulic conductivity using numerical simulations constrained by single-well aquifer tests: U.S. Geological Survey Water-Resources Investigations Report 2010-5004, 28 p. (Also available at http://pubs.usgs.gov/ sir/2010/5004/.)

Halford, K.J., 2006a, Documentation of a spreadsheet for time-series analysis and drawdown estimation: U.S. Geological Survey Scientific Investigations Report 2006-5024, 48 p. (Also available at http://pubs.usgs.gov/ sir/2006/5024/PDF/SIR2006-5024.pdf.)

Halford, K.J., 2006b, MODOPTIM—a general optimization program for ground-water flow model calibration and groundwater management with MODFLOW: U.S. Geological Survey Scientific Investigations Report 20065009, (Also available at http://pubs.usgs.gov/sir/2006/5009/ PDF/SIR2006-5009.pdf.)

Harbaugh, A.W., and McDonald, M.G., 1996, Programmer's documentation for MODFLOW-96, an update to the U.S. Geological Survey modular finite difference ground-water flow model: U.S. Geological Survey Open-File Report 96-486, 220 p. (Also available at http://pubs.er.usgs.gov/ publication/ofr96486.)

Harrison, J.C., 1971, New computer programs for the calculation of Earth tides: National Oceanic and Atmospheric Administration/University of Colorado, Cooperative Institute for Research in Environmental Sciences, $30 \mathrm{p}$.

IT Corporation, 1998, Report and analysis of the Bullion forced-gradient experiment: U.S. Department of Energy DOE/NV/13052-042, Las Vegas, Nev., 190 p.

Kruseman, G.P., and de Ridder, N.A., 1990, Analysis and evaluation of pumping test data (2d ed.): International Institute for Land Reclamation and Improvement, Publication 47, Wageningen, The Netherlands, 372 p. 
La Camera, R.J., Locke, G.L., and Habte, A.M., 2005, Selected ground-water data for Yucca Mountain region, southern Nevada and eastern California, January-December 2003: U.S. Geological Survey Open-File Report 2005-1286, 75 p. (Also available at http://pubs.usgs.gov/of/2005/1286/.)

Laczniak, R.J., Cole, J.C., Sawyer, D.A., and Trudeau, D.A., 1996, Summary of hydrogeologic controls on groundwater flow at the Nevada Test Site: U.S. Geological Survey Water-Resources Investigations Report 96-4109, 59 p. (Also available at http://pubs.usgs.gov/wri/wri964109/.)

McDonald, M.G., and Harbaugh, A.W., 1988, A modular three-dimensional finite-difference ground-water flow model: U.S. Geological Survey Techniques of WaterResources Investigations TWI 6-A1.

McKee, E.H., Phelps, G.A., and Mankinen, E.A., 2001, The Silent Canyon Caldera-A three-dimensional model as part of a Pahute Mesa-Oasis Valley, Nevada, hydrogeologic model: U.S. Geological Survey Open-File Report 01-297, 23 p.

Pawloski, G.A., Thompson, A.F.B., and Carle, S.F., 2001, Evaluation of the hydrologic source term from underground nuclear tests on Pahute Mesa at the Nevada Test Site-the CHESHIRE Test: Lawrence Livermore National Laboratory UCRL-ID-147023, 504 p.

Prothro, L.B., and Drellack, S.L. Jr., 1997, Nature and extent of lava-flow aquifers beneath Pahute Mesa, Nevada Test Site: Bechtel Nevada, Technical Report DOE/NV-11718156, 50 p.

Renard, P., 2005, The future of hydraulic tests: Hydrogeology Journal, v. 13, p. 259-262.

Sawyer, D.A., and Sargent, K.A., 1989, Petrographic evolution of divergent peralaline magmas from the Silent Canyon Caldera Complex, Southwestern Nevada Volcanic Field: Journal of Geophysical Research, v. 94, p. 6,021-6,040.

Stollar-Navarro Joint Venture (SNJV), 2009, Phase I transport model of corrective action units 101 and 102_central and western Pahute Mesa, Nevada Test Site, Nye County, Nevada: S-N/99205-111, 696 p.
Theis, C.V., 1935, The relation between the lowering of the piezometric surface and the rate and duration of discharge of a well using groundwater storage: American Geophysical Union Transactions, v. 16, p. 519-524.

U.S. Department of Energy, 2000, United States nuclear tests, July 1945 through September 1992: U.S. Department of Energy Report DOE/NV-209, Rev. 15.

U.S. Department of Energy, 1998, Completion report for well cluster ER-20-6: U.S. Department of Energy Report DOE/ NV-467/UC-700.

Walton, W.C., 2008, Upgrading aquifer test analysis: Ground Water Technical Commentary, v. 46, no. 5, p. 660-662.

Warren, R.G., Cole, G.L., and Walther, D., 2000, A structural block model for the three-dimensional geology of the Southwestern Nevada Volcanic Field: Los Alamos National Laboratory Report LA-UR-00-5866, 84 p.

Wolfsberg, A., Glascoe, L., Lu, G., Olson, A., Lichtner, P., McGraw, M., Cherry, T., and Roemer, G., 2002, TYBO/ BENHAM - model analysis of groundwater flow and radionuclide migration from underground nuclear tests in southwestern Pahute Mesa, Nevada: Los Alamos National Laboratory Report LA-13977, 490 p.

Wood, D.B., 2009, Digitally available interval-specific rocksample data compiled from historical records, Nevada Test Site and vicinity, Nye County, Nevada: U.S. Geological Survey Data Series 297, 56 p. (Also available at http://pubs. usgs.gov/ds/2007/297/.)

Yobbi, D.K., and Halford, K.J., 2008, Numerical simulation of aquifer tests, west-central Florida (revised): U.S. Geological Survey Scientific Investigations Report 2005-5201, 85 p. (Also available at http://pubs.usgs.gov/sir/2005/5201/.) 


\section{Appendix A. Modflow Files and Supporting Utilities}

All MODFLOW files and supporting utilities are in the zipped file, WW20-USGS.zip. The supporting utilities are batch files, FORTRAN programs, and macros in Microsoft $\bigcirc$ Excel workbooks. The zip file contains subfolders for the geologic framework, FORTRAN programs, and the calibration model (WW20-3D). Contents of all subdirectories and necessary software are reported in README file in the root directory of the unzipped WW20-USGS.zip file. These files are available for download at http://pubs.usgs.gov/sir/2011/5173/. 
This page intentionally left blank. 
Publishing support provided by the U.S. Geological Survey

Publishing Network, Tacoma Publishing Service Center

For more information concerning the research in this report, contact the Director, Nevada Water Science Center

U.S. Geological Survey

2730 N. Deer Run Road

Carson City, Nevada 89701

http://nevada.usgs.gov/ 


\section{贫}

禺

음.

言

울

I돈

홍

8

\%

क

홍

일

要

ISSN 2328-0328 (online) 